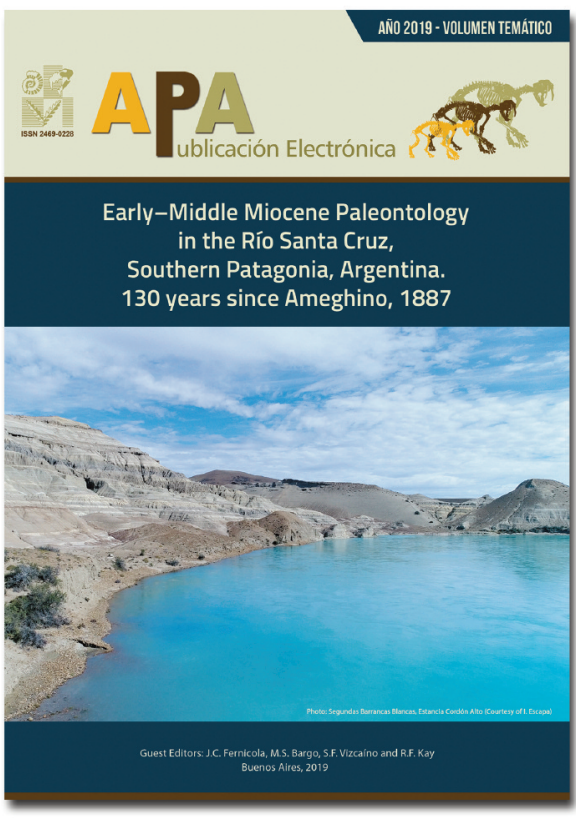

\title{
THE METATHERIA FROM THE RÍO SANTA CRUZ (SANTA CRUZ FORMATION, EARLY- MIDDLE MIOCENE, ARGENTINA): HISTORY AND NEW RECORDS
}

\author{
LAURA CHORNOGUBSKY1,2 \\ MARÍA A. ABELLO1,3 \\ GERMÁN D. BARMAK²
}

${ }^{1}$ Comisión Nacional de Investigaciones Científicas y Técnicas (CONICET).

¿Sección Paleontología Vertebrados, Museo Argentino de Ciencias Naturales "Bernardino Rivadavia". Av. Ángel Gallardo 470, C1405DRJ Ciudad Autónoma de Buenos Aires, Argentina.

${ }^{3}$ División Paleontología Vertebrados, Unidades de Investigación Anexo Museo, Facultad de Ciencias Naturales y Museo, Universidad Nacional de La Plata. Av. 122 y 60, B1904 La Plata, Argentina.

Recibido: 22 de marzo 2019 - Aceptado: 4 de octubre 2019

Para citar este artículo: Laura Chornogubsky, María A. Abello, and Germán D. Barmak (2019). The Metatheria from the Río Santa Cruz (Santa Cruz Formation, Early-Middle Miocene, Argentina): History and new records. Publicación Electrónica de la Asociación Paleontológica Argentina 19 (2): 62-84.

Link a este artículo: http://dx.doi.org/10.5710/PEAPA.04.10.2019.287

DESPLAZARSE HACIA ABAJO PARA ACCEDER AL ARTÍCULO

Asociación Paleontológica Argentina Maipú $6451^{\circ}$ piso, C1006ACG, Buenos Aires República Argentina

Tel/Fax (54-11) 4326-7563

Otros artículos en Publicación Electrónica de la APA 19(2): Web: www.apaleontologica.org.ar

\section{J.I. Cuitiño et al.}

STRATIGRAPHY AND DEPOSITIONAL ENVIRONMENTS OF THE SANTA CRUZ FORMATION (EARLY-MIDDLE MIOCENE) ALONG THE RÍO SANTA CRUZ, SOUTHERN PATAGONIA, ARGENTINA

\section{Fernández, N.A. Muñoz}

NOTOUNGULATA AND ASTRAPOTHERIA (MAMMALIA, MERIDIUNGULATA) OF THE SANTA CRUZ FORMATION (EARLY-MIDDLE MIOCENE) ALONG THE RÍO SANTA CRUZ, ARGENTINE PATAGONIA

\section{R.F. Kay, J.M.G. Perry}

NEW PRIMATES FROM THE RÍO SANTA CRUZ AND RÍO BOTE (EARLY-MIDDLE MIOCENE), SANTA CRUZ PROVINCE, ARGENTINA 


\title{
THE METATHERIA FROM THE RÍO SANTA CRUZ (SANTA CRUZ FORMATION, EARLY-MIDDLE MIOCENE, ARGENTINA): HISTORY AND NEW RECORDS
}

\author{
LAURA CHORNOGUBSKY1,2, MARÍA A. ABELLO1,3, AND GERMÁN D. BARMAK²
}

${ }^{1}$ Comisión Nacional de Investigaciones Científicas y Técnicas (CONICET).

Sección Paleontología Vertebrados, Museo Argentino de Ciencias Naturales "Bernardino Rivadavia". Av. Ángel Gallardo 470, C1405DRJ Ciudad Autónoma de Buenos Aires,Argentina.Ichorno@macn.gov.ar;.g_b_885@hotmail.com

${ }^{3}$ División Paleontología Vertebrados, Unidades de Investigación Anexo Museo, Facultad de Ciencias Naturales y Museo, Universidad Nacional de La Plata. Av. 122 y 60, B1904 La Plata, Argentina. mabello@fcnym.unlp.edu.ar

\begin{abstract}
Here we summarize the species of Metatheria from the Early-Middle Miocene Santa Cruz Formation at the Río Santa Cruz (RSC; Argentina). We assign newly collected specimens from the RSC localities Barrancas Blancas (BB) and Segundas Barrancas Blancas (SBB) to the known metatherian species. The metatherians from RSC were first described by F. Ameghino in 1887. He did not always establish clearly the type specimens of the species he founded, and often later he chose new type specimens. This led to confusion by future authors when they assumed they were looking at the original types when in fact they were the substitutes. We evaluated the actual and supposed type specimens from the RSC. We have identified the holotype of the Paucituberculata Palaeothentes aratae Ameghino and its calcotype. Following the International Code of Zoological Nomenclature (Art. 75), we formally propose neotypes, for the species Sipalocyon gracilis Ameghino (Sparassodonta) and for Microbiotherium patagonicum Ameghino (Microbiotheria). The species Perathereutes pungens Ameghino (Sparassodonta), previously known only from coastal localities, is described for the first time for the RSC. In total, we recognized 16 metatherian species for the RSC: seven Paucituberculata, seven Sparassodonta, and two Microbiotheria. Ten of the 16 species were recorded from recent fieldtrips. All 10 are recorded from SBB, six come from BB, and none from a third RSC locality, Yaten Huageno.
\end{abstract}

Key words. Marsupial. South America. Early Neogene. Santacrucian.

Resumen. LOS METATHERIA DEL RÍO SANTA CRUZ (FORMACIÓN SANTA CRUZ, MIOCENO TEMPRANO-MEDIO, ARGENTINA): HISTORIA Y NUEVOS REGISTROS. Con el objetivo de enumerar las especies de metaterios presentes en la Formación Santa Cruz (Mioceno TempranoMedio) en el Río Santa Cruz (RSC; Argentina) y determinar nuevos ejemplares de metaterios del RSC provenientes de las Barrancas Blancas (BB) y Segundas Barrancas Blancas (SBB), se procedió a identificar las especies conocidas para dicha localidad. Los metaterios del RSC fueron descriptos por primera vez por Ameghino en 1887 y, como fue común en sus trabajos, muy pocas veces estableció los ejemplares tipo de las especies por él fundadas o eligió nuevos ejemplares tipo. Esto llevó a que, en algunos casos, los investigadores posteriores tomaran como tipo especímenes que no lo eran. Se procedió al estudio de los tipos de las especies presentes en el RSC y a la determinación de los nuevos ejemplares colectados. El estudio dio como resultado el hallazgo del holotipo y calcotipo de Palaeothentes aratae Ameghino (Paucituberculata), la designación formal de dos neotipos siguiendo los requerimientos del Código Internacional de Nomenclatura Zoológica (Art. 75), para las especies Sipalocyon gracilis Ameghino (Sparassodonta) y Microbiotherium patagonicum Ameghino (Microbiotheria) y se determinó por primera vez para el RSC la especie Perathereutes pungens Ameghino (Sparassodonta), previamente conocida para localidades de la Costa Atlántica. Quedan entonces reconocidas un número total de 16 especies para el RSC: siete Paucituberculata, siete Sparassodonta y dos Microbiotheria. Diez de las 16 especies fueron registradas en las campañas recientes. Todas fueron halladas en SBB, mientras que solo seis provienen de BBy ninguna de la tercera localidad del RSC, Yaten Huageno.

Palabras clave. Marsupial. América del Sur. Neógeno temprano. Santacrucense.

The Santa Cruz Formation (SCF; Early-Middle Miocene; Burdigalian-early Langhian) forms extensive badlands with mudstones, tuffaceous sandstones, and tuffs cropping out in Southern Argentina, in an extended area of the Province of Santa Cruz. The unit can be studied in the northwest and southeast regions of the province, and in the central area along the Río Santa Cruz and Río Chalía (Vizcaíno et al., 2012; Fernicola et al., 2014; Cuitiño et al., 2016). The Río Santa Cruz (RSC) lies approximately at $50^{\circ}$ South in the Province of Santa Cruz and runs from west to east. 
Francisco P. Moreno in 1876-1877, following the steps of Fitz Roy (1837), navigated the RSC and explored the outcrops adjacent to its course finding, among other remains, the first marsupial from the SCF (Moreno, 1879, 1882; Fig. 1). In 1886, as director of the Museo de La Plata, Moreno commissioned Carlos Ameghino to carry out a paleontological and geological fieldtrip to the RSC. The trip lasted from January to September 1887 (Ameghino, 1887) and when Carlos returned to La Plata, his brother Florentino quickly studied many of the approximately 2000 fossils, and published an article in which he recognized 122 taxa (Fernicola, 2011), of which 19 are metatherian species (Ameghino, 1887).

The mammalian groups described by Ameghino (1887), currently regarded as metatherians, are Creodonta and Marsupialia. Among the Creodonta (Sparassodonta since Ameghino, 1894) from the RSC, he recognized the following species: Cladosictis patagonica Ameghino, 1887, Hathliacynus lustratus Ameghino, 1887, Agustylus cynoides Ameghino, 1887, Borhyaena tuberata Ameghino, 1887, Anatherium defossus Ameghino, 1887, Acrocyon sectorius Ameghino, 1887, Acyon tricuspidatus Ameghino, 1887, and Sipalocyon gracilis Ameghino, 1887. Later, Cabrera (1927) described the sparassodont Lycopsis torresi also from the RSC. In the recent literature, Agustylus cynoides, Hathliacynus lustratus, and Acrocyon sectorius are regarded as junior synonyms of Cladosictis patagonica (Marshall, 1981; Forasiepi, 2009; Prevosti and Forasiepi, 2018).
Ameghino recognized two families of Marsupialia: Plagiaulacidae (regarded later as Paucituberculata) and Microbiotheriidae. The former included Abderites meridionalis Ameghino, 1887, Acdestis oweni Ameghino, 1887, Palaeothentes aratae Ameghino, 1887, P. lemoinei Ameghino, 1887, P. pachygnatus Ameghino, 1887, P. intermedius Ameghino, 1887, P. pressiforatus Ameghino, 1887, and $P$. minutus Ameghino, 1887. Almost all these species are still considered valid today, except for $P$. pachygnatus and $P$. pressiforatus, each of which was regarded as a nomen vanum by Marshall (1980), because the types are lost and the descriptions are too scant to recognize the diagnostic features of the species. The Microbiotheriidae included Microbiotherium patagonicum Ameghino, 1887, M. tehuelchum Ameghino, 1887, and Stilotherium dissimile Ameghino, 1887. Stilotherium dissimile is considered a Paucituberculata Caenolestidae (Trouessart, 1898; Abello, 2013).

Ameghino's (1887) work was seminal for metatherian history in several aspects, since it includes the first description of a fossil fauna from the SCF, and it included the first fossil microbiotherians, paucituberculatans, and sparassodonts ever described (Ameghino, 1887, 1889).

The aim of this work is to reassess the taxonomic history of the metatherians from the RSC fauna identifying the type specimens of taxa named by Ameghino (1887), to study new specimens collected in recent years (Fernicola et al., 2019), and to give an updated list of species for the RSC as are now recognized.

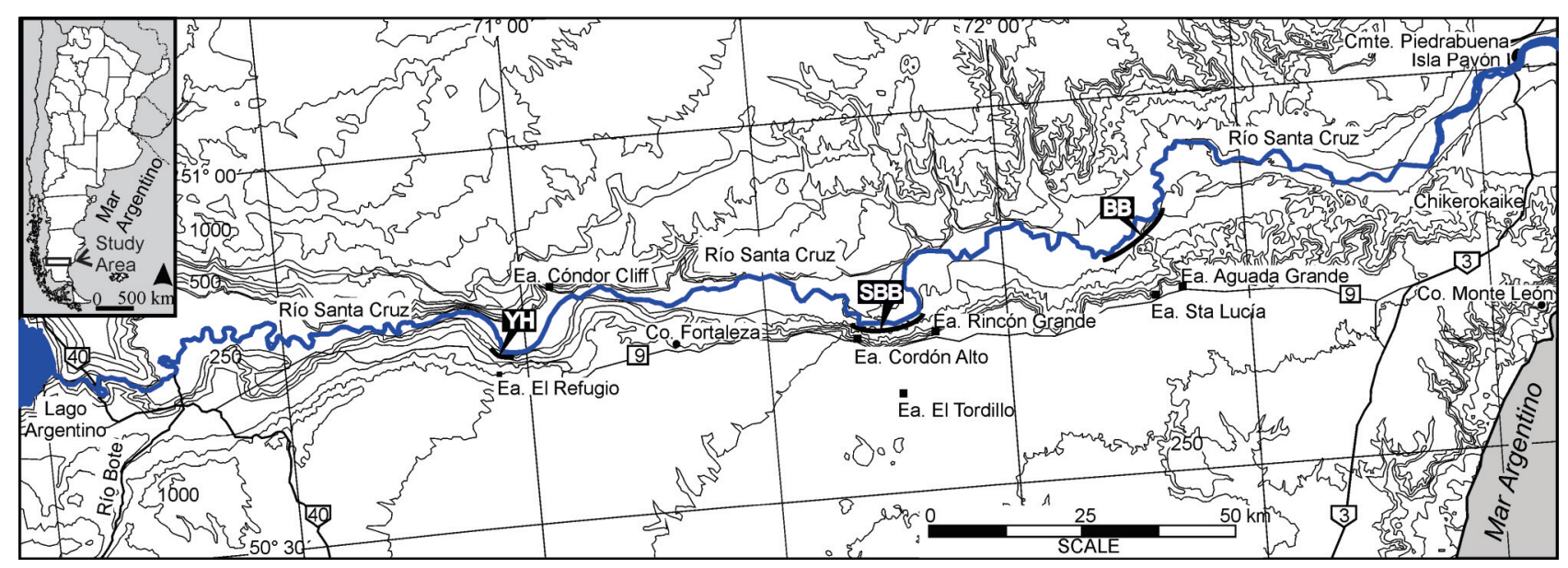

Figure 1. Map of Santa Cruz showing the Río Santa Cruz localities; BB, Barrancas Blancas; SBB, Segundas Barrancas Blancas; YH, Yaten Huageno. Modified from Fernicola et al. (2014). 


\section{MATERIAL AND METHODS}

Institutional abbreviations. MPM-PV, Museo Regional Provincial "Padre M. Jesús Molina", Colección de Paleovertebrados; MLP, Museo de La Plata; MACN-A, Museo Argentino de Ciencias Naturales "Bernardino Rivadavia", Colección Nacional Ameghino; MACN-Pv, Museo Argentino de Ciencias Naturales "Bernardino Rivadavia", Colección Nacional de Paleovertebrados; MACN-Pv SC, Museo Argentino de Ciencias Naturales "Bernardino Rivadavia", Colección Nacional de Paleovertebrados, Santa Cruz collection.

Anatomical abbreviations. c, lower canine; C, upper canine; Ltad, talonid length; Ltrgd, trigonid length; mx, lower molar in $\mathrm{x}$ position; $\mathbf{M x}$, upper molar in $\mathrm{x}$ position; px, lower premolar in $x$ position; $\mathrm{Px}$, upper premolar in $\mathrm{x}$ position; Wtad, talonid width; Wtrgd, trigonid width.

The new specimens presented in this paper were collected from the southern cliffs of the RSC at the localities Barrancas Blancas (BB, S $50^{\circ} 9^{\prime} 38.31^{\prime \prime}$ - W 69 40' 23.40" to $\left.S 50^{\circ} 12^{\prime} 31.70^{\prime \prime}-W 69^{\circ} 43^{\prime} 10.66^{\prime \prime}\right)$ and Segundas Barrancas Blancas (SBB, S 50 16' 12.48" - W 70 22' $23.21^{\prime \prime}$ to $\mathrm{S} 50^{\circ} 16^{\prime} 51.90^{\prime \prime}$ - W 70 17' 54.76") (Fernicola et al., 2014, 2019; Cuitiño et al., 2016). A third locality Yaten Huageno (YH) does not contain representatives of Metatheria. Barrancas Blancas crops out in Estancia Aguada Grande (EAG) and Estancia Santa Lucía (ESL). Segundas Barrancas Blancas crops out in Estancia Cordón Alto (ECA) and Estancia El Tordillo (EET) (Fernicola et al., 2014). The localities from the South-East of Province of Santa Cruz follow Vizcaíno et al. (2012) and Fernicola et al., (2019: fig. 1).

Ameghino $(1887,1889)$ considered that the marsupials had four premolars and three molars. However, this view was not shared by subsequent authors (e.g., Mercerat, 1891; Cabrera, 1927; Marshall, 1980, 1981, 1982), since the Metatheria dentary formula include three premolars and four molars. In the following descriptions we will use the present day homologies and we will included Ameghino's hypothesis between brackets [], when necessary.

The systematic arrange for the Sparassodonta, follows Marshall (1978, 1981), Forasiepi et al. (2006), Forasiepi (2009), Prevosti et al. (2012), and Prevosti and Forasiepi (2018). The Paucituberculata systematics, after Marshall (1980), Abello (2007, 2013), and Abello and Rubilar-Rogers (2012). For the Microbiotheria we follow Marshall (1982).

\section{SYSTEMATIC PALEONTOLOGY}

Infraclass Metatheria Huxley, 1880

Order Sparassodonta Ameghino, 1894

Family HathliaCINIDAE Ameghino, 1894

Genus Cladosictis Ameghino, 1887

Type species. Cladosictis patagonica Ameghino, 1887. Santa Cruz Formation, Barrancas del RSC, Province of Santa Cruz, Argentina.

Cladosictis patagonica Ameghino, 1887

Figure 2.1-7; Table 2

Holotype. MLP 11-103, left maxillary fragment with M3-4. Stratigraphic and geographic distribution. Río Frías Formation, Aysén (Chile); SCF, Province of Santa Cruz (Argentina) in the following localities: Puesto Estancia la Costa, Río Coyle, Cañadón Silva, Anfiteatro, Campo Barranca, Estancia La Costa, Karaiken, Cerro Observatorio, Río Gallegos, Río Chalía, Corriguen-Kaik, Cañadón Jack, Monte León, 10 miles South of Coy Inlet, Coy Inlet, Lago Pueyrredón, 10 miles North of Coy Inlet, Cañadón de Las Vacas, and RSC.

Referred material. MPM-PV 19416, right dentary fragment with emerging m3; MPM-PV 19417 (Fig. 2.1-7), several dentary fragments pertaining to two mandibles of the same individual; left dentary in two parts, one with $\mathrm{m} 4$ and other with m2-3 with broken cusps, right with canine, p1 and roots of $\mathrm{p} 2-3$, and several bone fragments; MPM-PV 19419, a lower canine; MPM-PV 19420, a lower canine.

Geographic distribution. SBB, all specimens come from ECA. Comments on the holotype. In his original description Ameghino (1887) described two teeth, M1-2 [P4-M1]. Both teeth were sectorial, with the posterior tooth smaller and transversely wider. In 1889 Ameghino described these teeth in more detail. From the description, the teeth are probably implanted in a single maxillary fragment. Mercerat (1891) commented on his list of sparassodonts from the MLP collections that the specimen described by Ameghino (1887) corresponds to an M3-4. Later, Cabrera (1927) assigned MLP 11-103 as the type of C. patagonica and agreed with Mercerat (1891) on the tooth positions and considered that Ameghino's identification was incorrect. Though incorrect in their position, Ameghino's (1887) description of the mo- 


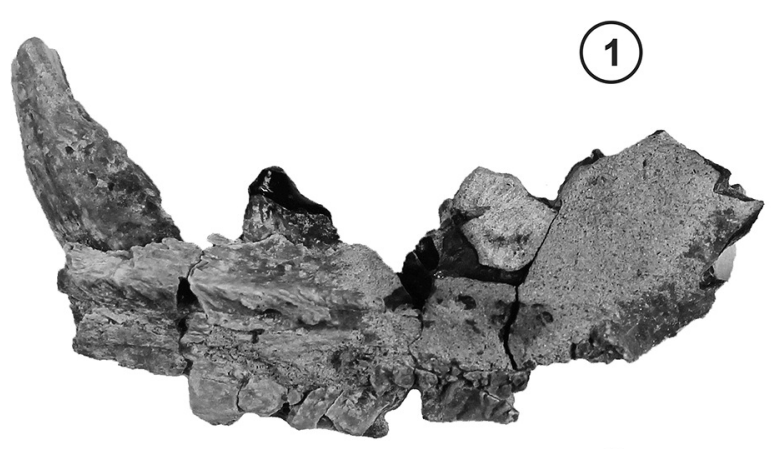

(3)

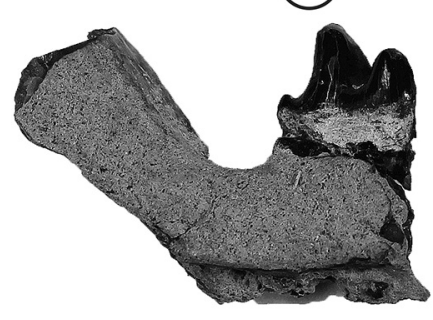

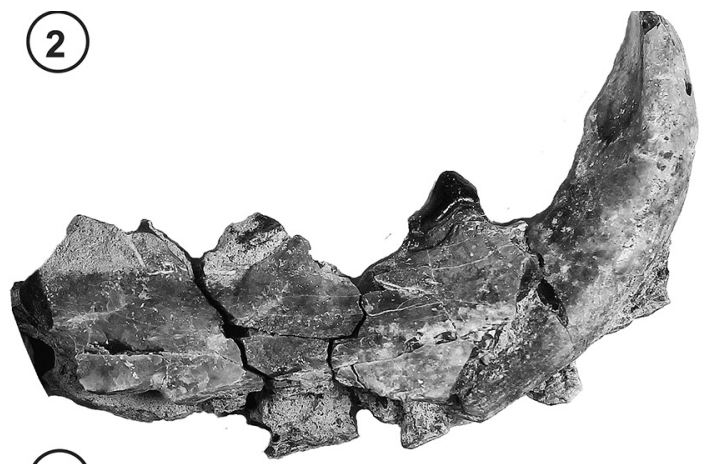

(4)

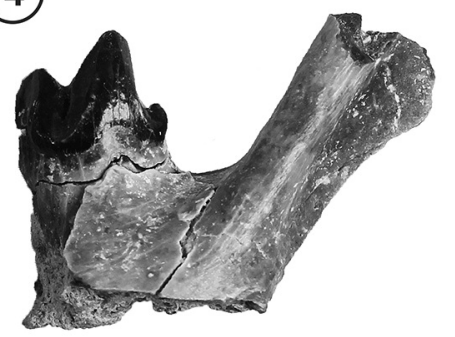

(5)

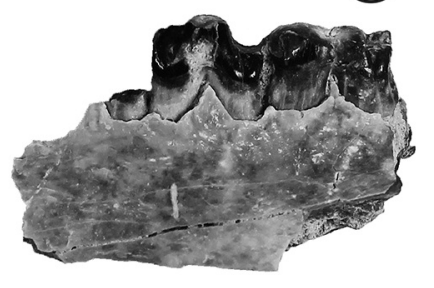

(6)

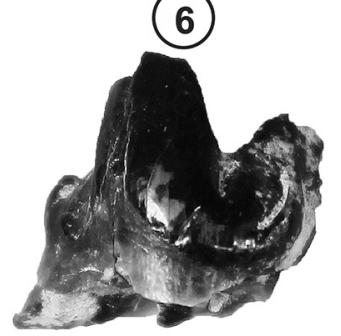

(7)

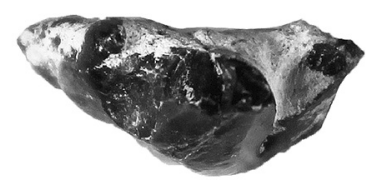

Figure 2. 1-7, Cladosictis patagonica, MPM-PV 19417; right dentary fragment with canine, p1 and roots of p2-3 in 1, lingual view; 2, labial view; left dentary fragment with $\mathrm{m} 4$ in 3, lingual view; 4, labial view; left dentary fragment with broken m2-3? in 5, labial view; isolated right $\mathrm{m} 4$ in 6, labial and 7, occlusal views. Scale bars $=10 \mathrm{~mm}$.

lars coincides with the MLP 11-103 (indicated as the type in the files from the MLP collections).

Comments on the referred material. The right mandible MPMPV 19416 corresponds to a juvenile individual with emerging $\mathrm{m} 3$, since the talonid is better developed than the one present in the $\mathrm{m} 4$ of this species. The specimen MPM-PV 19417 has several fragments and probably was a single individual, since the fragments were found in close proximity and the teeth show similar wear. The size and overall morphology of the molars and premolars are the ones expected for $C$. patagonica, as is the development of the canine, labiolingually broader when compare with other hathliacynids.

The two canines (MPM-VP 19419 and MPM-PV 19420) are here referred to C. patagonica by size and similarity to those present in other specimens of the species (e.g., MPM-PV 4333).
Genus Acyon Ameghino, 1887

Type species. Acyon tricuspidatus Ameghino, 1887. Santa Cruz Formation, Barrancas del RSC, Province of Santa Cruz, Argentina.

\section{Acyon tricuspidatus Ameghino, 1887}

Figure 3.1-4

Holotype. MLP 11-64, right dentary fragment in two parts, the anterior fragment with roots of $c$, alveoli for p1 and p2, and a posterior fragment with almost complete p3-m4.

Stratigraphic and geographic distribution. Santa Cruz Formation at the Province of Santa Cruz in the following localities: RSC, Río Chalía, and Cerro Observatorio.

Comments on the holotype. Ameghino (1887) described $A$. tricuspidatus as having eight lower molariforms. Later, 
TABLE 1 - Measurements of the lower molars of new RSC specimens described in this work

\begin{tabular}{|c|c|c|c|c|c|c|c|c|c|c|c|c|}
\hline & $\begin{array}{c}\text { Ltrgd } \\
\text { m1 }\end{array}$ & $\begin{array}{c}\text { Wtrgd } \\
\text { m1 }\end{array}$ & $\begin{array}{c}\text { Ltad } \\
\text { m1 }\end{array}$ & $\begin{array}{c}\text { Wtad } \\
\text { m1 }\end{array}$ & $\begin{array}{c}\text { Ltrgd } \\
m 2\end{array}$ & $\begin{array}{c}\text { Wtrgd } \\
m 2\end{array}$ & $\begin{array}{c}\text { Ltad } \\
\text { m2 }\end{array}$ & $\begin{array}{c}\text { Wtad } \\
\text { m2 }\end{array}$ & $\begin{array}{c}\text { Ltrgd } \\
\text { m3 }\end{array}$ & $\begin{array}{c}\text { Wtrgd } \\
\text { m3 }\end{array}$ & $\begin{array}{c}\text { Ltad } \\
\text { m3 }\end{array}$ & $\begin{array}{c}\text { Wtad } \\
\text { m3 }\end{array}$ \\
\hline \multicolumn{13}{|c|}{ Abderites meridionalis } \\
\hline MPM-PV 19374 & 3.35 & 1.68 & 2.27 & 1.43 & & & & & & & & \\
\hline MPM-PV 19375 & 3.40 & 2.01 & 2.14 & 1.50 & 1.45 & 1.66 & 1.69 & 1.61 & 0.82 & 1.40 & 1.70 & 1.11 \\
\hline \multicolumn{13}{|l|}{ Acdestis oweni } \\
\hline MPM-PV 19376 & - & - & - & 1.84 & 1.17 & 1.85 & 1.14 & 1.84 & 0.76 & 1.36 & 0.80 & 1.36 \\
\hline \multicolumn{13}{|c|}{ Borhyaena tuberata } \\
\hline MPM-PV 19321 & & & & & 7.61 & 4.91 & 3.05 & 5.94 & 8.90 & 5.46 & 2.30 & 6.89 \\
\hline \multicolumn{13}{|c|}{ Microbiotherium tehuelchum } \\
\hline MPM-PV 19372 & 0.83 & 0.81 & 0.61 & 1.66 & & & & & & & & \\
\hline MPM-PV 19373 & 0.75 & 0.93 & 1.11 & 1.20 & & & & & & & & \\
\hline \multicolumn{13}{|c|}{ Palaeothentes lemoinei } \\
\hline MPM-PV 19381 & 2.47 & 1.90 & 1.95 & 2.36 & - & - & - & - & & & & \\
\hline MPM-PV 19389 & & & & & 1.30 & 2.04 & 1.20 & 1.99 & 1.18 & 1.66 & 0.98 & 1.56 \\
\hline MPM-PV 19383 & 1.88 & 1.57 & 1.77 & 1.79 & 1.21 & 1.69 & 1.41 & 1.68 & 0.59 & 1.06 & 0.65 & 1.06 \\
\hline MPM-PV 19384 & 1.68 & 1.75 & 1.66 & 1.61 & 1.13 & 1.69 & 1.12 & 1.70 & 0.77 & 1.34 & 1.65 & 1.81 \\
\hline MPM-PV 19385 & 1.73 & 1.34 & 1.65 & 1.81 & 1.06 & 1.98 & 1.35 & 1.92 & & & & \\
\hline MPM-PV 19386 & 1.73 & 1.41 & 1.40 & 1.62 & 1.01 & 1.60 & 1.23 & 1.59 & 0.71 & 1.39 & 0.70 & 1.38 \\
\hline MPM-PV 19387 & & & & & 1.40 & 1.91 & 1.50 & 1.90 & 0.89 & 1.42 & 0.88 & - \\
\hline MPM-PV 19388 & & & & & 1.17 & 1.63 & 1.16 & 1.62 & - & - & - & - \\
\hline \multicolumn{13}{|c|}{ Palaeothentes minutus } \\
\hline MPM-PV 19379 & & & & & & & & & 0.72 & 1.54 & 1.01 & 1.55 \\
\hline MPM-PV 19391 & & & & & 0.70 & 1.06 & 0.72 & 1.07 & 0.56 & 0.74 & 0.57 & 0.73 \\
\hline MPM-PV 19392 & 0.94 & 0.90 & 0.95 & 0.93 & 0.48 & 1.15 & 0.63 & 1.10 & 0.40 & 1.02 & 0.44 & 1.04 \\
\hline MPM-PV 19393 & 0.83 & 0.82 & 0.93 & 0.82 & 0.63 & 1.01 & 0.70 & 1.02 & 0.61 & 0.97 & 0.63 & 0.98 \\
\hline MPM-PV 19395 & & & & & 0.62 & 1.18 & 0.65 & 1.18 & & & & \\
\hline MPM-PV 19396 & & & & & 0.61 & 1.17 & 0.62 & 1.17 & 0.46 & 0.95 & 0.50 & 0.95 \\
\hline MPM-PV 19398 & 0.81 & 0.88 & 0.91 & 0.92 & 0.64 & 1.01 & 0.75 & 1.03 & & & & \\
\hline MPM-PV 19399 & & & & & 0.85 & 1.35 & 0.92 & 1.35 & 0.49 & 0.94 & 0.70 & 0.94 \\
\hline MPM-PV 19401 & & & & & 0.55 & 1.11 & 0.57 & 1.11 & 0.37 & 0.90 & 0.36 & 0.90 \\
\hline MPM-PV 19402 & & & & & 0.58 & 0.91 & 0.59 & 0.91 & 0.25 & 0.82 & 0.29 & 0.82 \\
\hline MPM-PV 19403 & 0.59 & 0.64 & 0.76 & 0.90 & 0.62 & 0.78 & 0.67 & 0.78 & & & & \\
\hline MPM-PV 19409 & & & & & 0.73 & 0.96 & 0.75 & 0.96 & 0.42 & 0.87 & 0.43 & 0.87 \\
\hline MPM-PV 19405 & & & & & 0.73 & 0.90 & 0.74 & 0.90 & & & & \\
\hline MPM-PV 19406 & 0.84 & 0.80 & 0.86 & 0.85 & 0.53 & 1.00 & 0.56 & 1.01 & & & & \\
\hline \multicolumn{13}{|c|}{ Sipalocyon gracilis } \\
\hline MPM-PV 19413 & 3.57 & 1.65 & 0.97 & 1.64 & 3.89 & 2.57 & 1.13 & 2.42 & 4.78 & 3.02 & 1.76 & 2.49 \\
\hline MPM-PV 19415 & & & & & & & & & 5.54 & 3.98 & - & - \\
\hline \multicolumn{13}{|c|}{ Perathereutes pungens } \\
\hline MPM-PV 19410 & & & & & & & & & 3.59 & 2.66 & 1.11 & 1.44 \\
\hline
\end{tabular}

Measurements in mm. - Broken tooth did not allow taking measurement. Ltrgd: trigonid length; Wtrgd, trigonid width; Ltad, talonid length; Wtad, talonid width. 
Ameghino (1889) made a more thorough description of the specimen and mentioned that the mandible was in two pieces, the anterior part preserving from the symphyseal region to the second premolar and a posterior fragment with p3-m4 [p4-m4]. According to Mercerat (1891) the anterior fragment corresponds to Hathliacynus tricuspidatus and the posterior part to a different genus. Cabrera (1927) described the specimen MLP 11-64 and commented that the material was preserved like when Ameghino described it (Ameghino, 1887, 1889) and argued that the dentary formula included the canine, three premolars and four molars. Since Cabrera's work (Cabrera, 1927: fig. 6) some pieces broke a little more (e.g., the $\mathrm{p} 1$ is completely missing) and some were reconstructed (i.e., the p3 has the tip of the main cusp glue together but was not present in situ in Cabrera's figure). Cabrera (1927) considered Acyon as junior synonym of Cladosictis. Later Marshall (1981) considered $A$. tricuspidatus as junior synonym of Anatherium defossus. Finally, Forasiepi et al. (2006) recognized the genus Acyon and the species $A$. tricuspidatus when describing $A$. myctoderos, from the Miocene of Bolivia (see also Engelman et al., 2015).

Genus Sipalocyon Ameghino, 1887

Type species. Sipalocyon gracilis Ameghino, 1887. Santa Cruz Formation, Barrancas del RSC, Province of Santa Cruz, Argentina.

Sipalocyon gracilis Ameghino, 1887

Figure 4.1-5; Tables 1-3

Neotype (designated in this paper). MACN-A 647, right dentary fragment with alveoli of 1 1-3, root of the canine, alveolus of $\mathrm{p} 1$, and a complete $\mathrm{p} 2$.
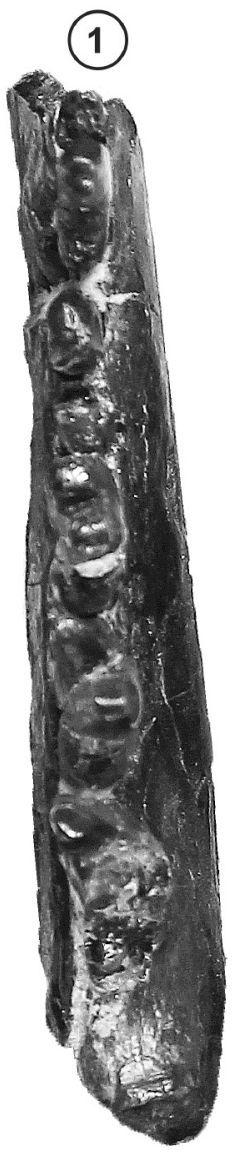

(2)

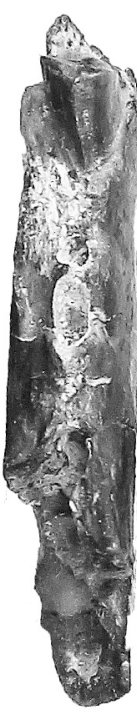

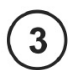

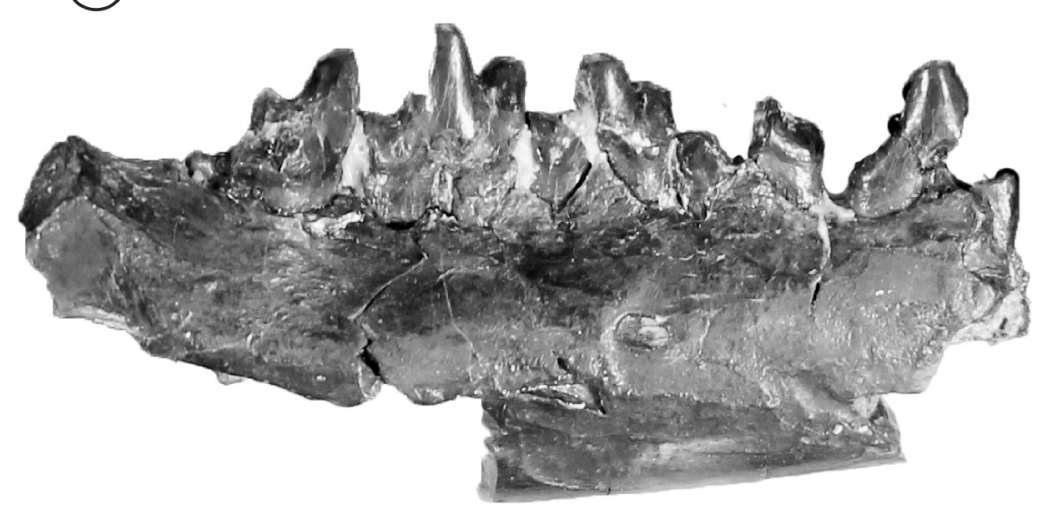

(4)

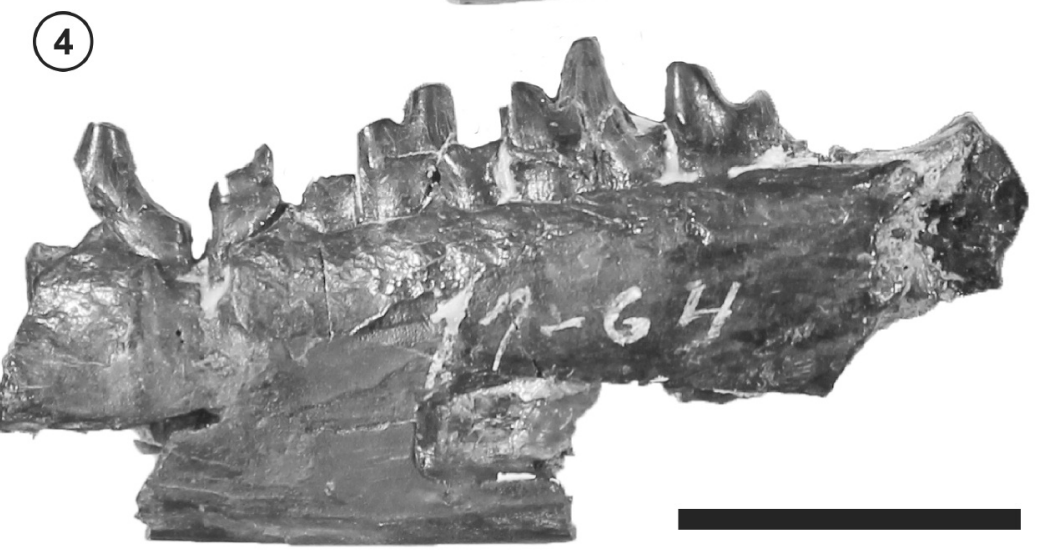

Figure 3. 1-4, Acyon tricuspidatus, MLP 11-64 (type specimen); 1, 3-4, right dentary posterior fragment with p3-m4 in 1, occlusal view; 3, labial view; 4, lingual view; 2, right dentary anterior fragment with roots of c, alveoli for p1 and p2 in occlusal view. Scale bar= $20 \mathrm{~mm}$. 


\begin{tabular}{|c|c|c|c|c|c|c|c|c|c|c|c|c|c|}
\hline & W & $L$ & W & $L$ & W & $L$ & $w$ & $L$ & $w$ & $L$ & W & $L$ & $w$ \\
\hline & $C$ & p1 & p1 & p2 & $p 2$ & p3 & p3 & P1 & P1 & P2 & $P 2$ & P3 & P3 \\
\hline \multicolumn{14}{|l|}{ Acdestis oweni } \\
\hline MPM-PV 19376 & & & & & & 1.12 & - & & & & & & \\
\hline MPM-PV 19478 & & & & & & & & & & & & 2.46 & 1.78 \\
\hline \multicolumn{14}{|c|}{ Microbiotherium tehuelchum } \\
\hline MPM-PV 19372 & & & & & & 0.92 & 0.63 & & & & & & \\
\hline \multicolumn{14}{|c|}{ Palaeothentes lemoinei } \\
\hline MPM-PV 19382 & & & & & & & & & & 1.73 & 0.72 & 3.26 & 1.77 \\
\hline MPM-PV 19390 & & & & & & & & & & & & 2.48 & 1.80 \\
\hline MPM-PV 19384 & & & & & & 1.70 & 1.15 & & & & & & \\
\hline MPM-PV 19385 & & & & & & 1.87 & 1.17 & & & & & & \\
\hline MPM-PV 19386 & & & & & & 1.19 & 0.91 & & & & & & \\
\hline \multicolumn{14}{|c|}{ Palaeothentes minutus } \\
\hline MPM-PV 19391 & & & & & & 1.15 & 0.65 & & & & & & \\
\hline MPM-PV 19393 & & & & & & 0.86 & 0.58 & & & & & & \\
\hline MPM-PV 19494 & & & & & & 1.28 & 0.66 & & & & & & \\
\hline MPM-PV 19408 & & & & & & 1.01 & 0.55 & & & & & & \\
\hline MPM-PV 19398 & & & & & & 0.94 & 0.80 & & & & & & \\
\hline \multicolumn{14}{|c|}{ Sipalocyon gracilis } \\
\hline MPM-PV 19413 & 3.31 & & & & & & & 3.59 & 1.72 & 4.90 & 1.90 & 5.00 & 2.29 \\
\hline \multicolumn{14}{|c|}{ Perathereutes pungens } \\
\hline MPM-PV 19410 & & 3.27 & 1.66 & 4.43 & 1.67 & & & & & & & & \\
\hline \multicolumn{14}{|c|}{ Cladosictis patagonica } \\
\hline MPM-PV 19419 & 5.90 & - & & & & & & & & & & & \\
\hline MPM-PV 19420 & 6.40 & - & & & & & & & & & & & \\
\hline
\end{tabular}

Stratigraphic and Geographic distribution. Río Frías Formation at Aysén (Chile) and in the SCF, Province of Santa Cruz (Argentina) in the following localities: Cerro Observatorio, Monte León, La Cueva, Río Chalía, Yegua Quemada, Killik Aike Norte, Estancia La Costa, Puesto Estancia La Costa (= Corriguen Kaik), Cañadón de las Vacas, 10 miles South from Coy Inlet. Referred material. MPM-PV 19411, left isolated M4; MPMPV 19412, skull fragment, right and left isolated M3, and right maxillary fragment with $\mathrm{P} 2-3$, probably from the same individual (Fig. 4.1-2); MPM-PV 19413, left dentary fragment with c-m3 (Fig. 4.3-5); MPM-PV 19414, an isolated left M3.
Geographic distribution. BB: MPM-PV 19411 comes from EAG and MPM-PV 19412 comes from ESL. SBB: MPM-PV 19413 was recovered from EET and MPM-PV 19414, from ECA.

Neotype designation. The specimen MACN-A 647 is designated here as the neotype following Art. 75 (75.3.1 to 75.3.7) of the International Code of Zoological Nomenclature, in order to clarify the taxonomic status of the species (Art. 75.3.1). This can be done after establishing that the original type (e.g., holotype, syntypes) is lost (Art. 15.3.4).

When Ameghino (1887) first described this species, he mentioned the measurements of the base of the canine, 


\begin{tabular}{|c|c|c|c|c|c|c|c|c|}
\hline & $w$ & $L$ & $W$ & $L$ & $w$ & $L$ & $w$ & $L$ \\
\hline & M1 & M1 & M2 & M2 & M3 & M3 & M4 & M4 \\
\hline \multicolumn{9}{|l|}{ Acdestis oweni } \\
\hline MPM-PV 19377 & & & & & 1.64 & 1.30 & & \\
\hline MPM-PV 19378 & 3.70 & 2.01 & 2.47 & 1.99 & 1.81 & 1.53 & 1.30 & 1.28 \\
\hline \multicolumn{9}{|c|}{ Borhyaena tuberata } \\
\hline MPM-PV 19424 & & & & & 9.66 & 4.86 & & \\
\hline \multicolumn{9}{|c|}{ Palaeothentes minutus } \\
\hline MPM-PV 19397 & & & & & 1.79 & 1.14 & & \\
\hline MPM-PV 19400 & & & 1.47 & 1.42 & & & & \\
\hline \multicolumn{9}{|l|}{ Sipalocyon gracilis } \\
\hline MPM-PV 19414 & & & & & 6.59 & 4.13 & & \\
\hline MPM-PV 19412 & & & & & $4.71 ?$ & - & & \\
\hline MPM-PV 19418 & & & 4.71 & - & & & & \\
\hline
\end{tabular}

Measurements in mm. - Broken tooth did not allow to take measurement. W: width, L: Length.

and he described the $\mathrm{p} 1$, and his p4-m2 (i.e., m1-3). Later, Ameghino (1889) commented that the monospecific genus Sipalocyon was represented by a very incomplete left dentary, but with the base of the canine and almost all its molars severly broken. In Ameghino's unpublished catalogue, the specimen 647 (housed at the MACN-A collection) corresponds to a right dentary fragment with alveoli for i13 , root of the canine, alveoli of the $\mathrm{p} 1$, and complete $\mathrm{p} 2-\mathrm{m} 2$, and it states tipo. In 1894 (fig. 55) and in 1898 (fig. 58.e) Ameghino figured this specimen to illustrate $S$. gracilis. MACN-A 647 was then considered as the type by succeeding authors (e.g., Marshall, 1981; Forasiepi, 2009), even though it does not coincide with Ameghino's original description in 1887 or the one from 1889, and was exhumed from SCF levels of Cerro Observatorio (= Monte Observación). When Marshall (1981) study the Hathliacyninae, he assigned several specimens to $S$. gracilis, but only two specimens come from the RSC, MLP 11-7 (type of Hathliacynus lynchi Mercerat, 1891) and MLP 11-25. Even though is tempting to consider one of these two specimens as the original type from Ameghino (1887, 1889), there are no correspondence with the preserved loci of these mandibles and the type. After reviewing these specimens and looking for the missing type in both MLP and MACN-A collections, we concluded that it is lost (Art. 75.3.4). We conclude that MACN-A 647 corresponds to the original descriptions of Ameghino (1887, 1889; Art. 75.3.2, 75.3.3, and 75.3.5) and was collected in the same geological unit (SCF; Art. 75.3.6). Moreover, it was considered as the type by the specialists since Ameghino (1894; see also Marshall, 1981; Forasiepi, 2009), thus preserving the name and concept stability.

Comments on the referred material. The specimen MPM-PV 19411 is an isolated M4, with size and transversal development similar to the ones expected for S. gracilis (e.g., see MACN-A 691-703). That is why, even though it is an isolated specimen, we assign it to the species.

MPM-PV 19414, an isolated M3, has a broken protocone and the paracone and metacone are shorter than the ones from other specimens assigned to this species, though the stylar shelf and size is similar to the one from it. However, as for the MPM-PV 19411, an assignment to S. gracilis is made.

Genus Perathereutes Ameghino, 1891

Type species. Perathereutes pungens Ameghino, 1891. Santa Cruz Formation, Cerro Observatorio, Province of Santa Cruz, Argentina.

Perathereutes pungens Ameghino, 1891

Figure 4.6-14 


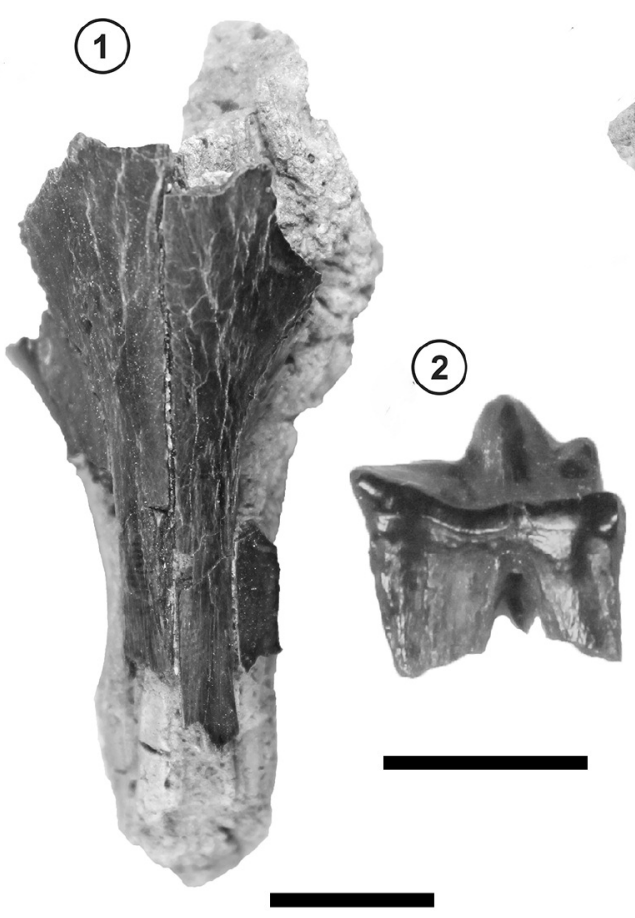

(3)

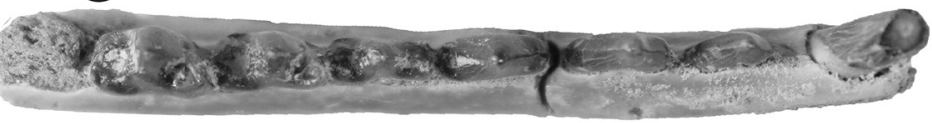

(6)
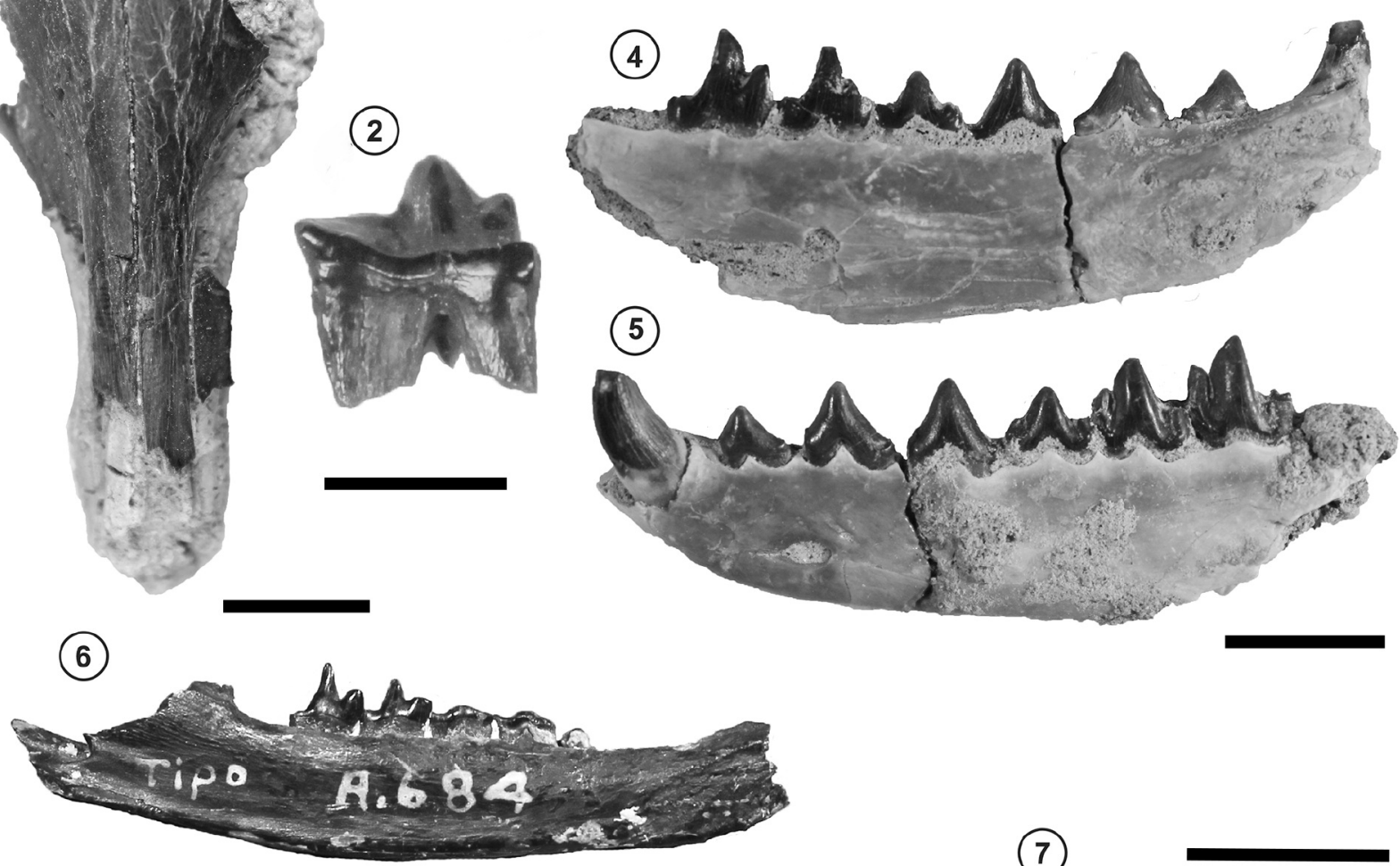

(7)

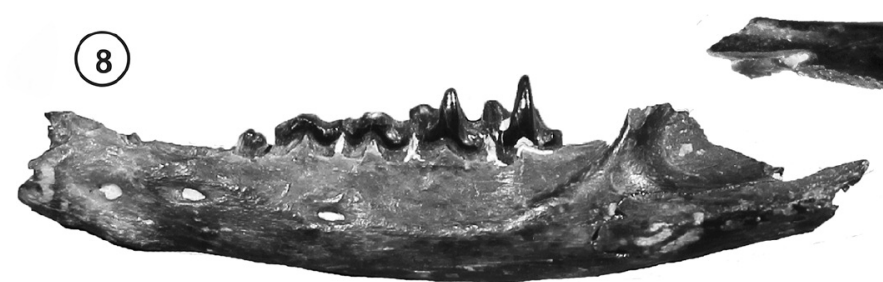

(9)

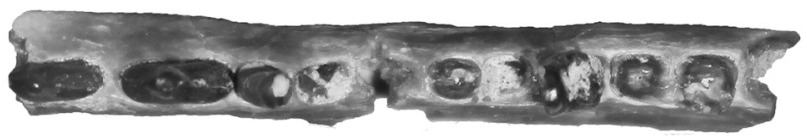

(10)

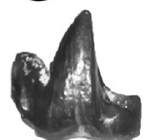

(11)

(12)
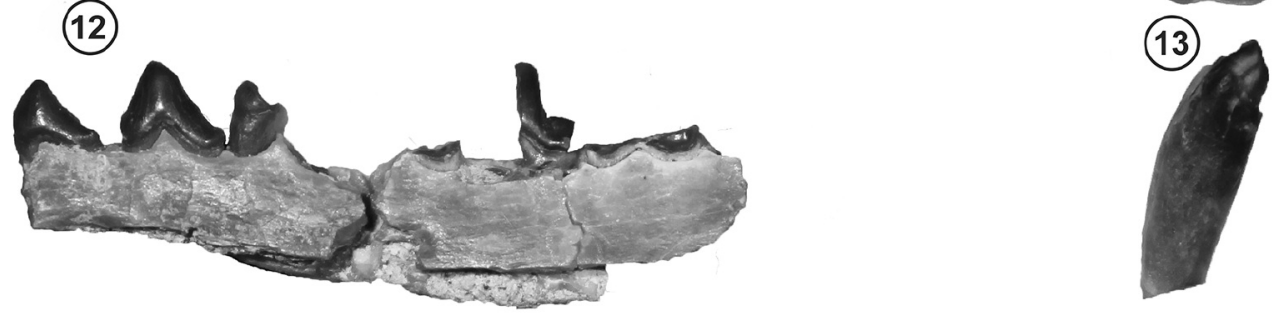

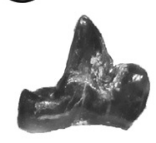

(14)

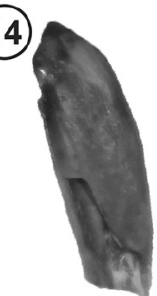

Figure 4. 1-5, Sipalocyon gracilis, MPM-PV 19412; 1, cranial fragment in dorsal view; 2, left isolated M3 in posterolingual view, MPM-PV 19413; 3, occlusal view; 4, lingual view; 5, labial view; 6-14, Perathereutes pungens, MACN-A 684 (type specimen); 6, lingual view; 7, occlusal view; 8, labial view; MPM-PV 19410; right mandible with p1-2, and roots of p3-m3 in 9, occlusal view; 12, lingual view; m3 in 10, labial view; 11 , lingual view; and upper canine in 13, labial view; 14, lingual view. Scale bars $=10 \mathrm{~mm}$. 
Holotype. MACN-A 684, left dentary fragment with alveolus of the canine, roots of p1-3, and complete m1-4 (Fig. 4.6-8). Stratigraphic and Geographic distribution. Santa Cruz Formation
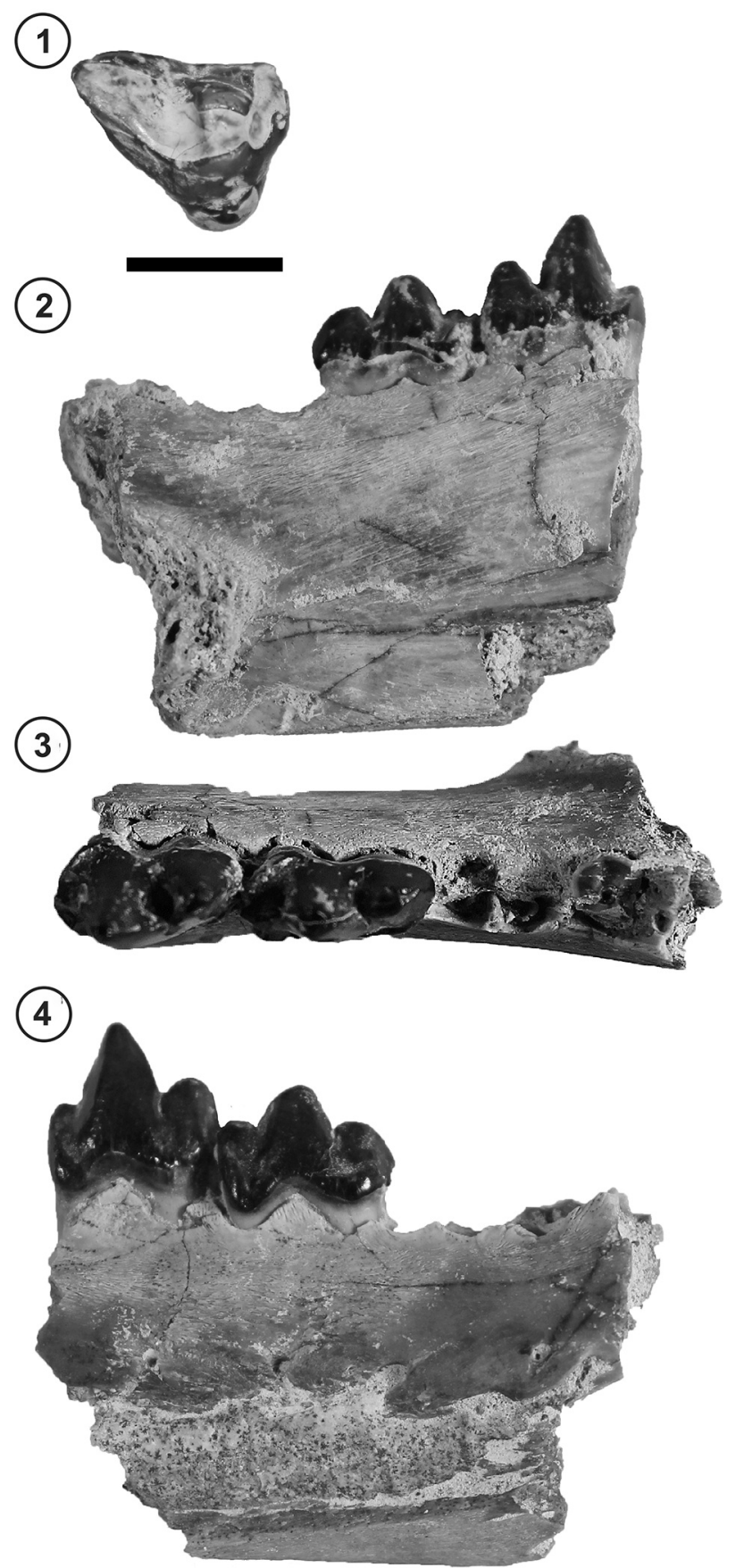

Figure 5. 1-4, Borhyaena tuberata, MPM-PV 19424; 1, occlusal view, MPM-PV 19421; 2, lingual view; 3, occlusal view; 4, labial view. Scale bars $=10 \mathrm{~mm}$. at the Province of Santa Cruz in Cerro Observatorio, La Cueva, and Puesto Estancia la Costa.

Referred material. MPM-PV 19410, left dentary fragment with p1 and p2, anterior root of p3, alveoli for $\mathrm{m} 1$, roots of $\mathrm{m} 2$, and talonid of $\mathrm{m} 3$, and an isolated $\mathrm{m} 3$, from the same individual but the contact of the roots is almost lost so it cannot be glue together (Fig. 4.9-14).

Geographic distribution. SBB: MPM-PV 19410 comes from ECA. Measurements. Tables 1 and 2.

Comments on the referred material. Perathereutes pungens has been considered very similar to with Sipalocyon gracilis (see Marshall, 1981), but is considered as a valid genus and species (e.g., Prevosti et al., 2012; Ercoli et al., 2014; Prevosti and Forasiepi, 2018). Both species are very similar but they have some distinguishable differences in size, $P$. pungens being smaller than S. gracilis and its talonid is less developed than in S. gracilis in all lower molars. The specimen MPM-PV 19410 is of smilar size to the holotype. The molar talonids are less developed than the ones from S. gracilis (i.e., the hypoconid is less salient). A broken canine is preserved and probably was part of the same individual. This tooth is very gracile.

This is the first time that Perathereutes pungens is mentioned for the RSC. This discovery not only improves the knowledge of this species, but also extends its distribution to the West.

\section{Superfamily Borhyaenoidea Ameghino, 1894 \\ Family Borhyaenidae Ameghino, 1894}

Genus Borhyaena Ameghino, 1887

Type species. Borhyeaena tuberata Ameghino, 1887. Santa Cruz Formation, Barrancas del RSC, Province of Santa Cruz, Argentina.

\section{Borhyaena tuberata Ameghino, 1887}

Figure 5.1-4; Table 1

Holotype. MLP 11-108, an isolated left P3.

Stratigraphic and geographic distribution. Aysén (Río Frías Formation; Chile); In the SCF at the Province of Santa Cruz, the following localities: RSC, Río Coyle, Puesto Estancia La Costa (= Corriguen Aike), Campo Barranca, Anfiteatro, Karaiken, Yegua Quemada, Cerro Observatorio, La Cueva, 6, 10, 
and 12 miles South of Río Coyle, Estancia Angelina, Monte León.

Referred material. MPM-PV 19421, right dentary fragment with roots of p3-m1 and complete m1-2 (Fig. 5.2-4); MPMPV 19424, an isolated right M2 (Fig. 5.1).

Geographic distribution. BB: MPM-PV 19421 comes from EAG; SBB: MPM-PV 19424 comes from ECA.

Comments on the referred material. Both specimens have similar size and talonid development as in other specimens of B. tuberata (see e.g., MACN-A 6203-6265). MPM-PV 19424 , though being an isolated $\mathrm{M} 2$, has a vestigial protocone and despite heavy cuspal wear, a paracone is seen to have been large, as occurs on the M2 of B. tuberata (MACNA 9341).

\section{Genus Acrocyon Ameghino, 1887}

Type species. Acrocyon sectorius Ameghino, 1887. Santa Cruz Formation, Barrancas del RSC, Province of Santa Cruz, Argentina.

\section{Acrocyon sectorius Ameghino, 1887}

Figure 6.1-3

Holotype. MLP 11-70, a right dentary fragment with roots of dp3? and complete m1 (Fig. 6.1-3).

Stratigraphic and geographic distribution. Santa Cruz Formation, Province of Santa Cruz at the following localities: RSC, Río Chalía, and 5 miles south of Coy Inlet.

Comments on the holotype. In his original description Ameghino (1887) described this species as having the last premolars and the first true molars with three cusps on the sectorial line and then provided measurements of the $\mathrm{m} 1$ [p4]. Later, Ameghino (1889) commented that the genus Acrocyon was erected based on a mandibular fragment with a large complete tooth, probably the $\mathrm{m} 1$ [p4] or $\mathrm{m} 2$ [m1]. Mercerat (1891) considered that the preserved tooth corresponded to the $\mathrm{m} 2$. Cabrera (1927) recognized the type of the species (MLP 11-70) and agreed with Mercerat (1891) concerning the assignment of the single tooth from the mandibular fragment to be the $\mathrm{m} 2$. He also described the roots of the anterior, broken tooth. Because of the features of the broken locus, he considered it as the m1, but Marshall (1978) argued that these roots are part, probably, of a deciduous p3.

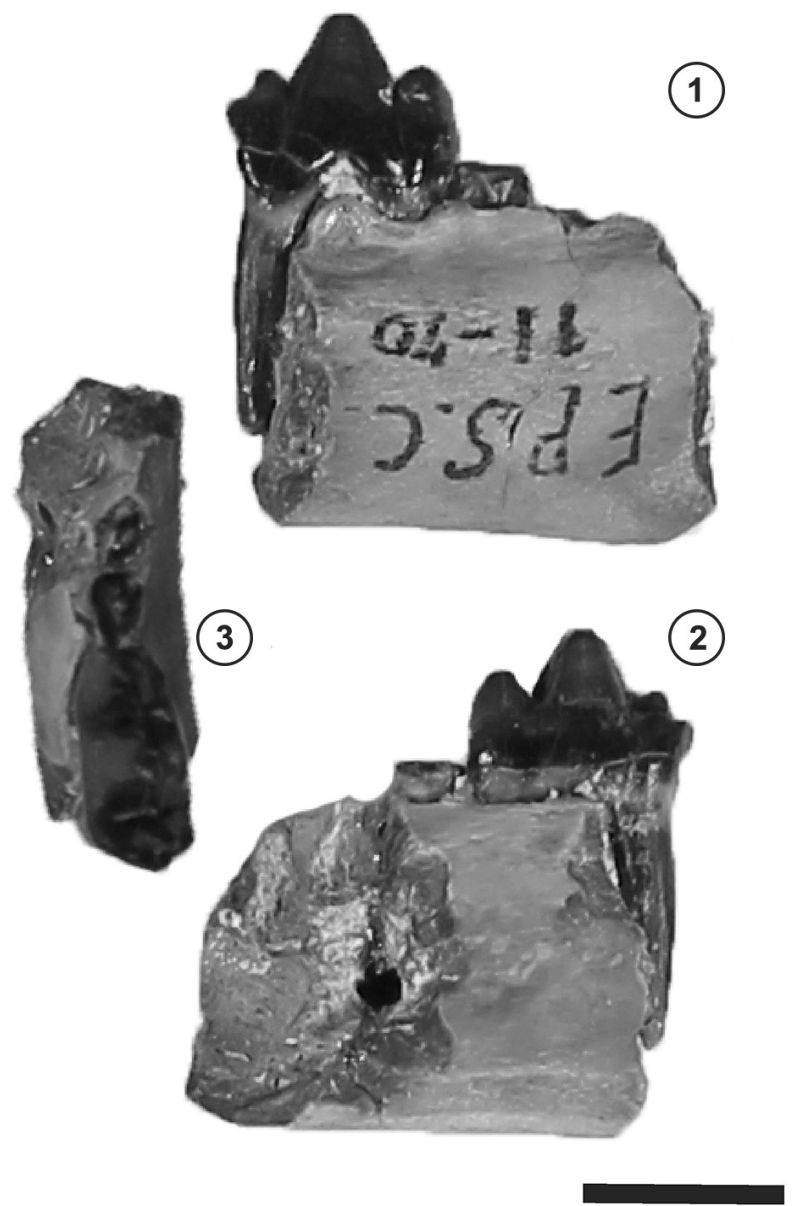

Figure 6. 1-3, Acrocyon sectorius, MLP 11-70 (type specimen); 1 , lingual view; 2, occlusal view; 3, labial view. Scale bar $=10 \mathrm{~mm}$.

Genus Lycopsis Cabrera, 1927

Type species. Lycopsis torresi Cabrera, 1927. Santa Cruz Formation, RSC, Province of Santa Cruz, Argentina.

\section{Lycopsis torresi Cabrera, 1927}

Figure 7.1-4

Holotype. MLP 11-113, two maxillary fragments with M1-4, and a left Px; two mandibles with an incomplete dentition (Fig. 7.1-4).

Stratigraphic and geographic distribution. Santa Cruz Formation, RSC, Estancia la Costa, Province of Santa Cruz, Argentina.

Comments on the holotype. Lycopsis torresi was first described by Cabrera (1927) with only the holotype. The specimen comes from the Río Santa Cruz and was recovered by $C$. Berry in July 1895. 
(1)

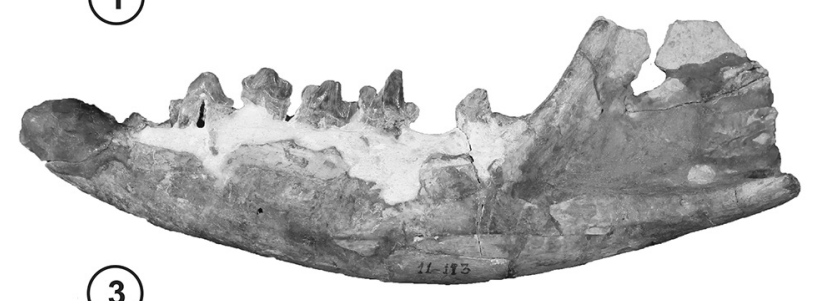

(3)

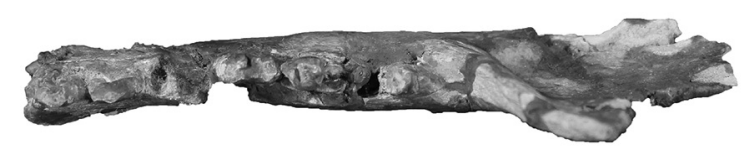

(2)

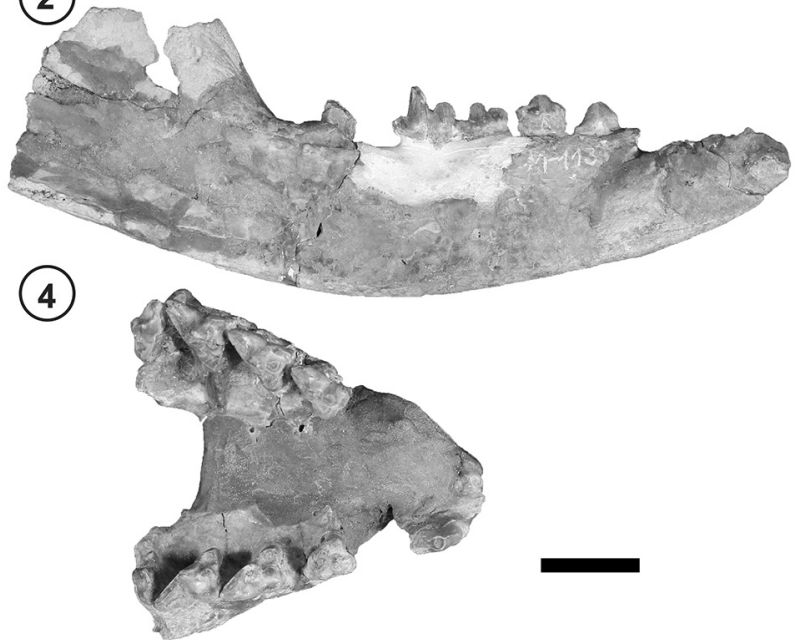

Figure 7. 1-4, Lycopsis torresi, MLP 11-113 (type specimen); left mandible in 1, labial view; 2, lingual view; right mandible in 3, occlusal view; left and right maxillaries with M1-4 in 4, occlusal view. Scale bar $=20 \mathrm{~mm}$.

Supercohort MarSUPIALIA Gill, 1872

Orden Paucituberculata Ameghino, 1894

Superfamily CAENolestoIdEA Trouessart, 1898

Family CaEnolestidae Trouessart, 1898

Genus Stilotherium Ameghino, 1887

Type species. Stilotherium dissimile Ameghino, 1887. Santa Cruz Formation, Barrancas del RSC, Province of Santa Cruz, Argentina.

Stilotherium dissimile Ameghino, 1887

Neotype. MACN-A 8464, a right dentary fragment with i2-m4 (Reig, 1955).

Stratigraphic and geographic distribution. Santa Cruz Formation, Province of Santa Cruz in the following localities: RSC, Cerro Observatorio, La Cueva, San Jorge, Río Chalía.

Comments on the holotype. The type of this species is lost, as previously noted by other authors (Reig, 1955; Marshall, 1980). The MACN collection has a specimen labeled as type by Ameghino (MACN-A 5723). However, this specimen does not coincide with Ameghino's (1887) description and was not found during the fieldtrip to the Santa Cruz river by C. Ameghino in 1887 but was collected in the expedition of 1890-1891 at Monte Observación (= Cerro Observatorio). Reig (1955) named the specimen MACN-A 8464 as the neotype because of the completeness of the specimen, even though it does not come from the RSC but from La Cueva. The neotype was accepted by subsequent authors (e.g., Marshall, 1980; Abello, 2007).

We add this taxon to the current study because the original type came from this locality (Ameghino, 1887).

\section{Superfamily Palaeothentoidea Sinclair, 1906}

Family AbdeRITIDAe (Ameghino, 1889)

Genus Abderites Ameghino, 1887

Type species. Abderites meridionalis Ameghino, 1887. Santa Cruz Formation, Barrancas del RSC, Province of Santa Cruz, Argentina.

Abderites meridionalis Ameghino, 1887

Figure 8.1-5; Table 1

Holotype. MACN-A 12, right mandibular fragment with complete m1-3 (Fig. 8.1-3).

Stratigraphic and Geographic distribution. From Pinturas Formation at Province of Santa Cruz: Cerro de los Monos, Cauce seco, Los Toldos, Estancia El Carmen, Loma de la Lluvia, Loma de las Ranas, Portezuelo Sumich Norte, Portezuelo Sumich Sur, Cañadón del Tordillo; from Province of Chubut, at Gran Barranca. From the SCF, Province of Santa Cruz: RSC, Cerro Observatorio, La Cueva, Río Chalía, Cerro Centinela, and Lago Cardiel. 
Referred material. MPM-PV 19374, an isolated m1 (Fig. 8.45); MPM-PV 19375, right dentary fragment with m1-3 (Fig. 8.6-7).

(1)

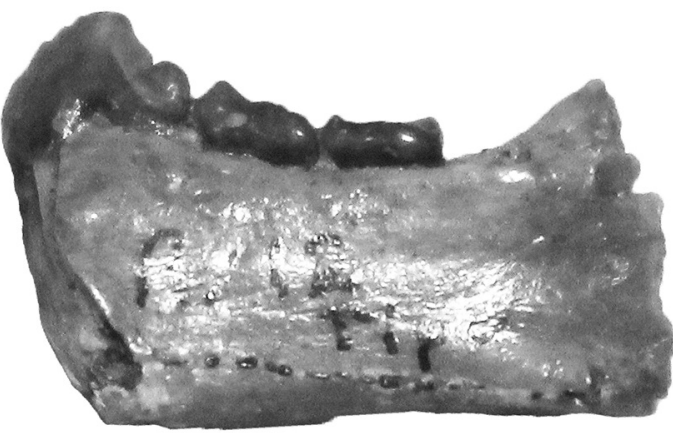

(2)

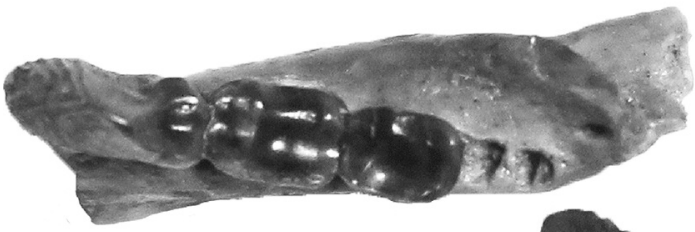

(3)

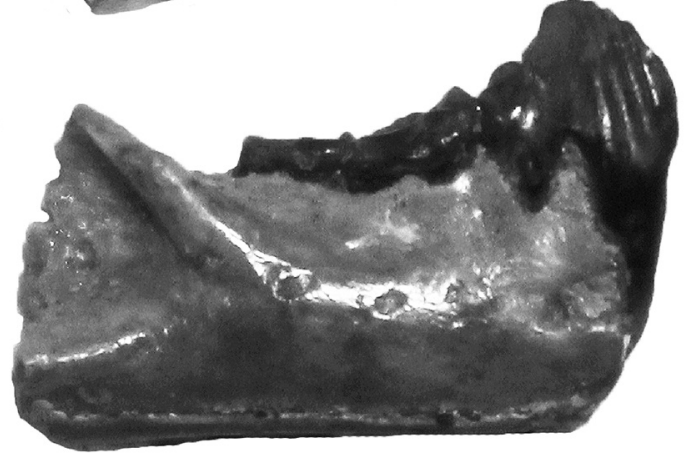

(4)

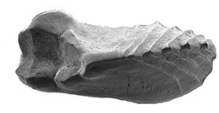

(5)

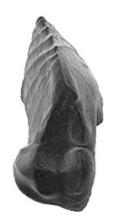

(6)

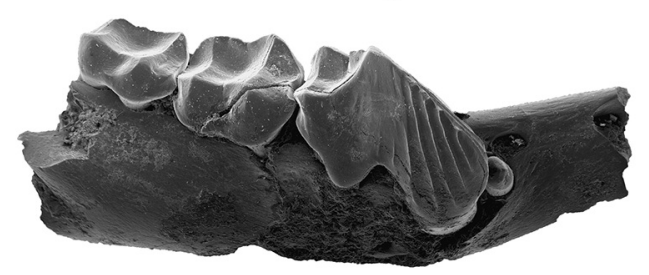

(7)

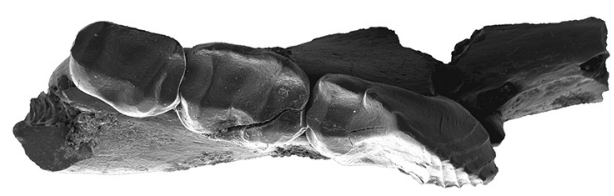

Figure 8. 1-7, Abderites meridionalis, MACN-A 12 (type specimen); 1, lingual view; 2, occlusal view; 3, labial views; MPM-PV 19374; 4, occlusal view; 5, posterior view; MPM-PV 19375; 6, occluso-labial view; 7, oclusal view. Scale bar $=2 \mathrm{~mm}$.
Geographic distribution. BB: MPM-PV 19374 comes from EAG; SBB: MPM-PV 19375 comes from ECA.

Comments on the referred material. The specimens we assign to $A$. meridionalis have the diagnostic features observed for this species (Abello and Rubilar-Rogers, 2012). Moreover, the $\mathrm{m} 1$ from MPM-PV 19374 and MPM-PV 19375 have a well developed talonid, with the hypoconid more salient than the expected for other species of the genus, and the dentary MPM-PV 19375 has a diastema mesial to the $\mathrm{p} 3$, and the $\mathrm{m} 2$ is larger than $\mathrm{m} 1$.

Family Palaeothentidae Sinclair, 1906

Subfamily ACDESTINAE Sinclair, 1906

Genus Acdestis Ameghino, 1887

Type species. Acdestis oweni Ameghino, 1887. Santa Cruz Formation at RSC, Province of Santa Cruz, Argentina.

\section{Acdestis oweni Ameghino, 1887 \\ Figure 9.1-6; Tables 1-3}

Holotype. MACN-A 1379, right dentary fragment with broken first incisor, complete p3-m1, and trigonid of m2 (Fig. 9. 1-2).

Stratigraphic and geographic distribution. Collón Cura Formation at Cañadón del Tordillo (Province of Neuquén, Argentina); SCF at the Province of Santa Cruz in the following localities: Monte León, Cerro Observatorio, Lago Cardiel, Gobernador Gregores, Río Chalía, and RSC.

Referred material. MPM-PV 19376, a left dentary fragment with p3-m4 (Fig. 9. 3-4; MPM-PV 19377, an isolated left M3; MPM-PV 19378, a right maxillary fragment with P3M4 (Fig. 9.5-6).

Geographic distribution. BB: MPM-PV 19376 comes from EAG; SBB: MPM-PV 19377 and MPM-PV 19378 come from ECA. Comments on the referred material. The specimen MPM-PV 19376 is very worn, but the tooth proportions and size are similar to that expected for $A$. oweni, where the $\mathrm{m} 1$ is large when compared to the very reduced $\mathrm{m} 3$ and $\mathrm{m} 4$.

Likewise, the specimens with upper teeth (MPM-PV 19377 and MPM-PV 19378) agree with other samples of $A$. oweni (e.g., MACN-Pv SC 1461) in terms of size, and cusp and crest arrangement. 


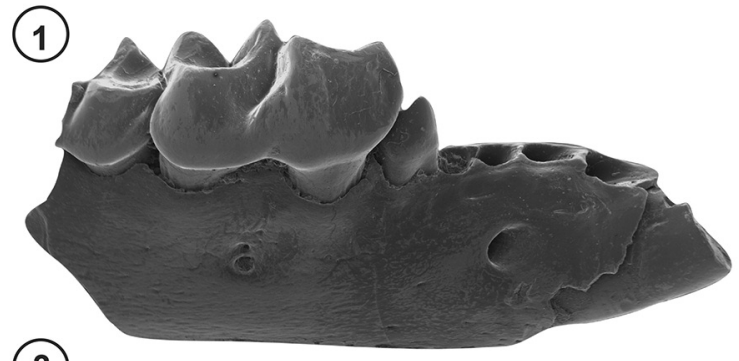

(3)

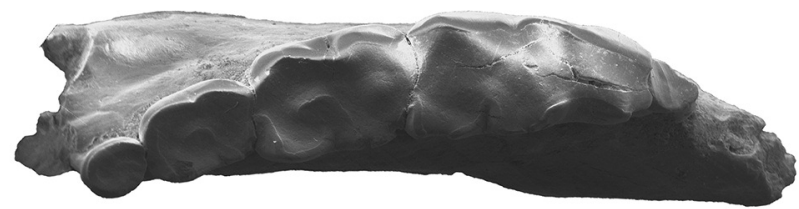

(5)

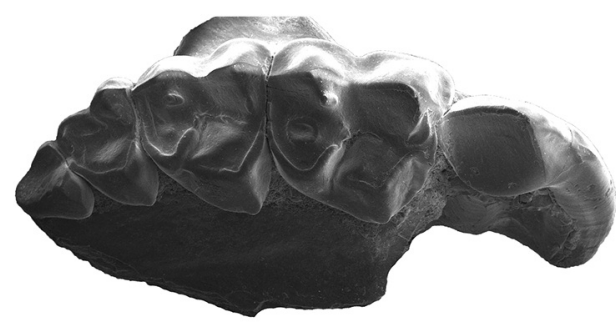

(2)

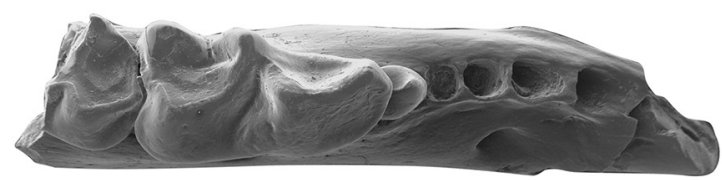

(4)

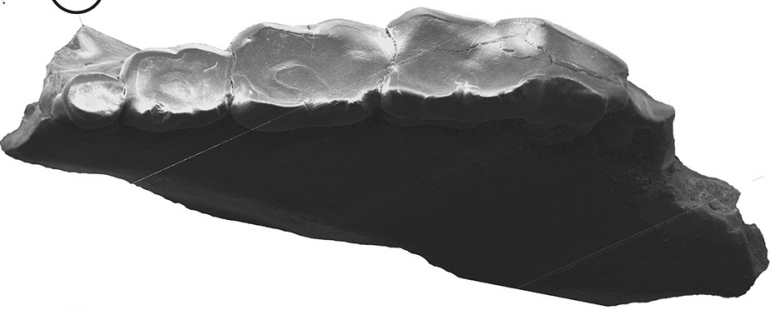

(6)

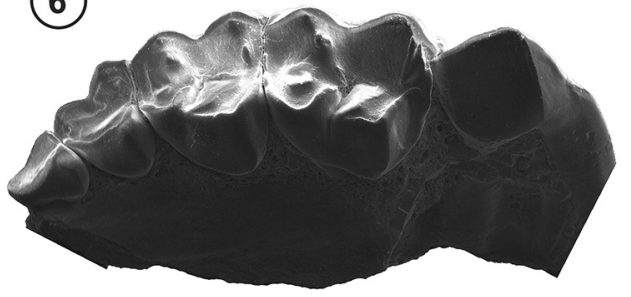

Figure 9. 1-6, Acdestis owenii, MACN-A 1379 (type specimen); 1, labial view; 2, occlusal view; MPM-PV 19376; 3, occlusal view; 4, lingual view; MPM-PV 19378; 5, occlusal view; 6, occluso-lingual view. Scale bar= 2 mm.

Subfamily Palaeothentinae Sinclair, 1906

Genus Palaeothentes Ameghino, 1887

Type species. Palaeothentes aratae Ameghino, 1887. Santa Cruz Formation, Barrancas del RSC, Province of Santa Cruz, Argentina.

\section{Palaeothentes aratae Ameghino, 1887}

Figure 10.1-4

Holotype. MLP 11-93, right dentary fragment with roots of p2, p3, m1, m2, and m4 (Fig. 10.3-4).

Calcotype. MACN-A 1340, right dentary fragment with complete $\mathrm{m} 1$, trigonid of $\mathrm{m} 2$, roots of p2, p3, and $\mathrm{m} 4$ (Fig. 10.1-2).

Stratigraphic and geographic distribution. Santa Cruz Formation at the Province of Santa Cruz in the following localities: RSC, Río Chalía, Cerro Observatorio, Río Gallegos, and Monte León.

Comments on the holotype. Moreno (1882) collected the type specimen from the SCF at the RSC and named it Palaeothentes aratae. Later, Ameghino (1887) defined and described the species based on Moreno's findings. The original designation by Moreno is considered as nomen nudum (see Marshall, 1980) and Ameghino (1887) is considered as the author of the species by posterior designation (see Abello, 2007). In 1889, Ameghino redescribed the species as Epanorthus aratae (Ameghino, 1887) and commented that Moreno (1882) based its species on a single mandibular fragment with a complete $\mathrm{m} 1$ and a broken $\mathrm{m} 2$ [p4-m1], both very worn. Ameghino (1889) illustrated the specimen collected by Moreno in his Atlas (pl. 1; fig. 11; see also Marshall, 1980). However, on his catalogue, he numbered as type the specimen MACN-A 14, represented by a much more complete mandibular fragment with less worn p3-m4, used as the holotype by subsequent authors (e.g., Sinclair, 1906; Marshall, 1980; Bown and Fleagle, 1993). However, this specimen is not the one collected by Moreno, since it 
was recovered by C. Ameghino (1890-1891; Marshall, 1980) and does not come from the RSC but from Cerro Observatorio (unpublished catalogue of F. Ameghino).

In Ameghino's collection at MACN there are a few casts representing a single dentary fragment numbered 1340 and named as Epanorthus aratae. Different authors considered specimen 1340 as pertaining to P. aratae (e.g., Marshall, 1980). This specimen corresponds to the cast of the material figured by Ameghino (1889: pl. 1, fig. 11) and in Ameghino's catalogue figured as collected by Moreno, thus being the original calcotype. Marshall (1980) commented that the original type should have been in the MLP collections but is currently lost. However, in the MLP collection appears the MLP 11-93, considered as $P$. aratae by several authors (e.g., Marshall, 1980; Abello, 2007). It corresponds to a right dentary fragment with broken teeth, and part of the mandible glue together. We suggest that MACN-A 1340 is the cast of MLP 11-93, with the teeth broken off after the original description, thus being the holotype of $P$. aratae.
(1)

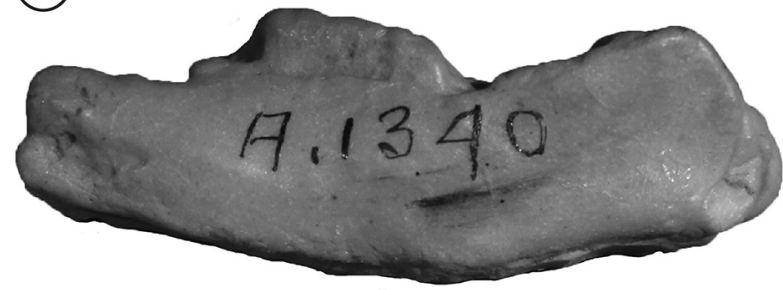

(3)

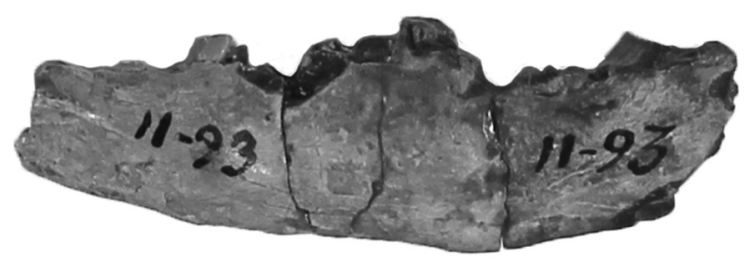

(6)

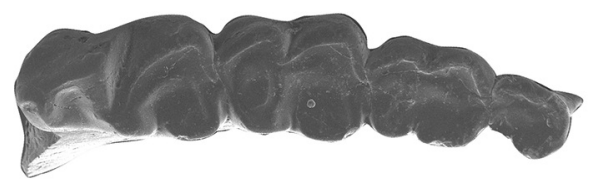

(8)

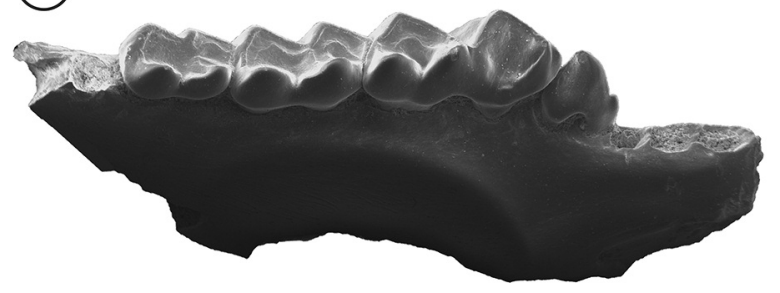

(2)

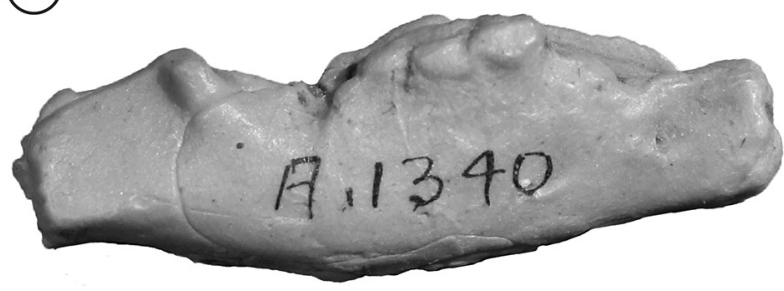

(4)

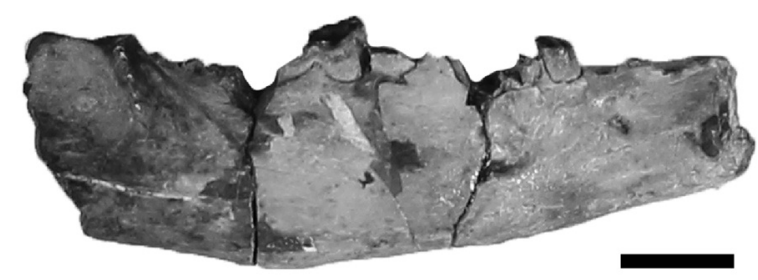

(7)

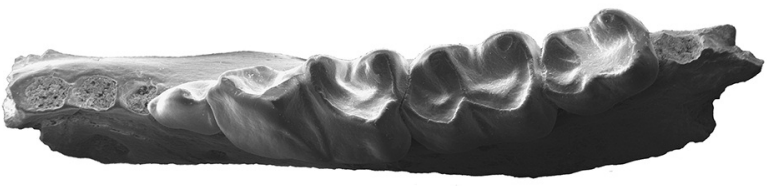

(9)

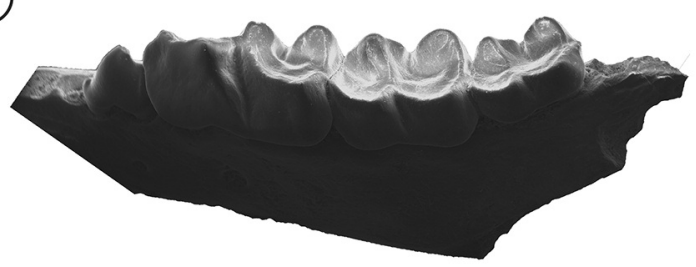

Figure 10. 1-5, Palaeothentes aratae, MACN-A 1340 (calcotype); 1, lingual view; 2, labial view; MLP 11-93; 3, lingual view; 4, labial view; 6-9, Palaeothentes lemoinei, MACN-A 3 (type specimen); 6, occlusal view; MPM-PV 19386; 7, occlusal view; 8, labial view; 9, lingual view. Scale bars $=2 \mathrm{~mm}$. 
Palaeothentes lemoinei Ameghino, 1887

Figure 10.6-9; Tables 1, 2

Holotype. MACN-A 3, a right dentary fragment with complete m1-4 (Fig. 10.6).

Stratigraphic and geographic distribution. Santa Cruz Formation, Province of Santa Cruz in the following localities: Cerro Observatorio, Monte León, Puesto Estancia la Costa, La Cueva, Yegua Quemada, Río Chalía, and RSC.

Referred material. MPM-PV 19381, right dentary fragment with $\mathrm{m} 1$ and broken m2; MPM-PV 19382, right maxillary fragment with P2-3; MPM-PV 19390, left dentary fragment with p3 and broken m1-2; MPM-PV 19383, right dentary fragment with m1-3; MPM-PV 19384, right dentary fragment with p3-m3; MPM-PV 19385, left dentary fragment with p3-m2; MPM-PV 19386, left dentary fragment with p3-m3 (Fig. 10.7-9); MPM-PV 19387, left dentary fragment with m2-3; MPM-PV 19388, right dentary fragment with m2-3; MPM-PV 19389, right dentary fragment with m2-3. Geographic distribution. BB: MPM-PV 19381 and MPM-PV 19383 come from ESL, MPM-PV 19389 comes from EAG; SBB: MPM-PV 19382 comes from EET, and MPM-PV 19384, MPM-PV 19385, MPM-PV 19386, MPM-PV 19387, MPM-PV 19388, and MPM-PV 19390 come from ECA.

Comments on the referred material. As seen in Bown and Fleagle (1993) the size and some proportions on the $\mathrm{m} 3$ are quite variable in $P$. lemoinei, and all specimens assigned here are encompassed within this variation. In particular, MPMPV 19383, a dentary fragment with $\mathrm{m} 1-3$ has a relatively small m3 when compared to the holotype, but this variant can be observed in other specimens assigned to the species (e.g., MACN-Pv SC 2953 from Río Chalía and MACN-Pv SC 3025, from Cerro Observatorio).

The MPM-PV 19381 and MPM-PV 19390 are very broken and worn, but their overall size and proportions coincides with that of $P$. lemoinei, that is why are here referred to it.

Palaeothentes intermedius Ameghino, 1887

Figure 11.1-2; Table 1

Lectotype. MACN-A 2, right dentary fragment with complete p3-m3 (Marshall, 1980) (Fig. 11.1-2).
Stratigraphic and geographic distribution. All specimens come from the Province of Santa Cruz (Argentina). Pinturas Formation at Río Pinturas: Estancia Los Toldos, Estancia Ana María, Estancia El Carmen, Gobernador Gregores, Cueva de las Manos, and Lago Cardiel. Santa Cruz Formation: Yegua Quemada, Río Chalía, La Cueva, Cerro Observatorio, Monte León, Estancia La Cañada, RSC.

Referred material. MPM-PV 19380, left dentary fragment with $\mathrm{m} 2$ and lingually broken m3; MPM-PV 19394, left dentary fragment with $\mathrm{p} 3$, and trigonid of $\mathrm{m} 1$.

Geographic distribution. BB: MPM-PV 19394 from EAG; SBB: MPM-PV 19380 from ECA.

Comments on the lectotype. Ameghino (1887) described the species on the basis of features of the dentary and lower teeth. Later, Ameghino (1889) commented that the species was based on several specimens and in his unpublished catalogue at MACN collection he considered MACN-A 2 to be the type. MACN-A 2 is figured in Ameghinos's Atlas (pl.1, fig. 15) thus being part of the syntype (from SCF beds in the RSC), even though no data appear in the MACN museum catalog (see Marshall, 1980). In his revision of the Caenolestidae Marshall designated MACN-A 2 as type, even recognizing that other specimens could be part of the syntype. Today, not all of the other specimens constituting the syntype can be located with certainty, but MACN-A 2 has been used by Marshall (1980) and later by other authors (e.g., Marshall, 1980; Bown and Fleagle, 1993; Abello, 2007) as the type of the species.

The ICZN, in its Art. 74.1 states that "A lectotype may be designated from syntypes to become the unique bearer of the name of a nominal species-group taxon and the standard for its application". Since it was known to Marshall (1980) that originally the species was defined by a syntype (Ameghino, 1889), it can be assumed that the specimen labelled as type by Marshall (1980) was considered in this sense a lectotype, and applying Art. 74.5 he is considered as the first author of the lectotype.

Comments on the referred material. Specimen MPM-PV 19380 is very worn but it is assigned to $P$. intermedius on behalf of its size and tooth proportions. MPM-PV 19394 preserves only the p3 and the trigonid of the m1. However, we assigned to the species on behalf of its paracristid, almost parallel to the dentary axis, and bifurcates almost at the an- 

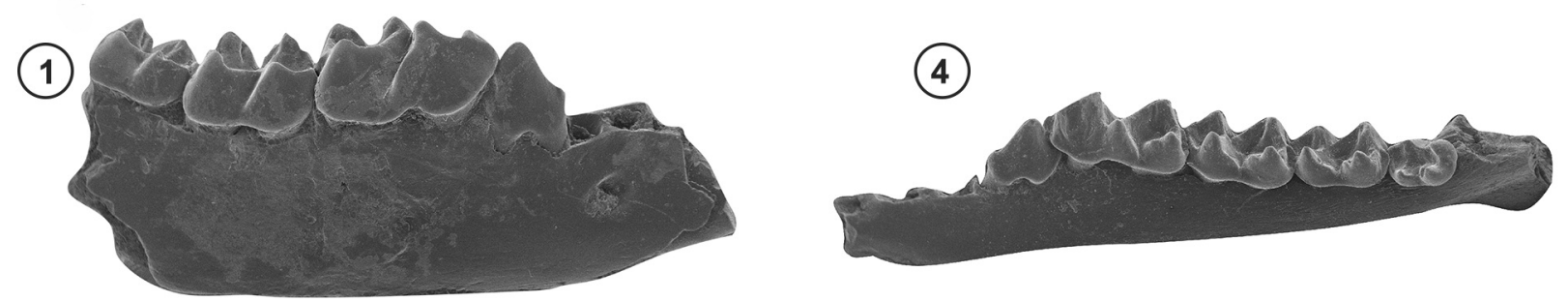

(2)

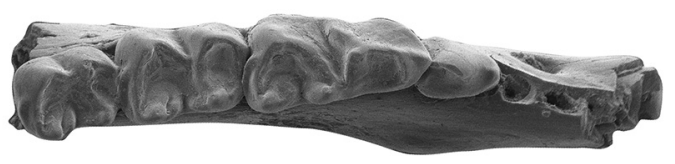

(3)
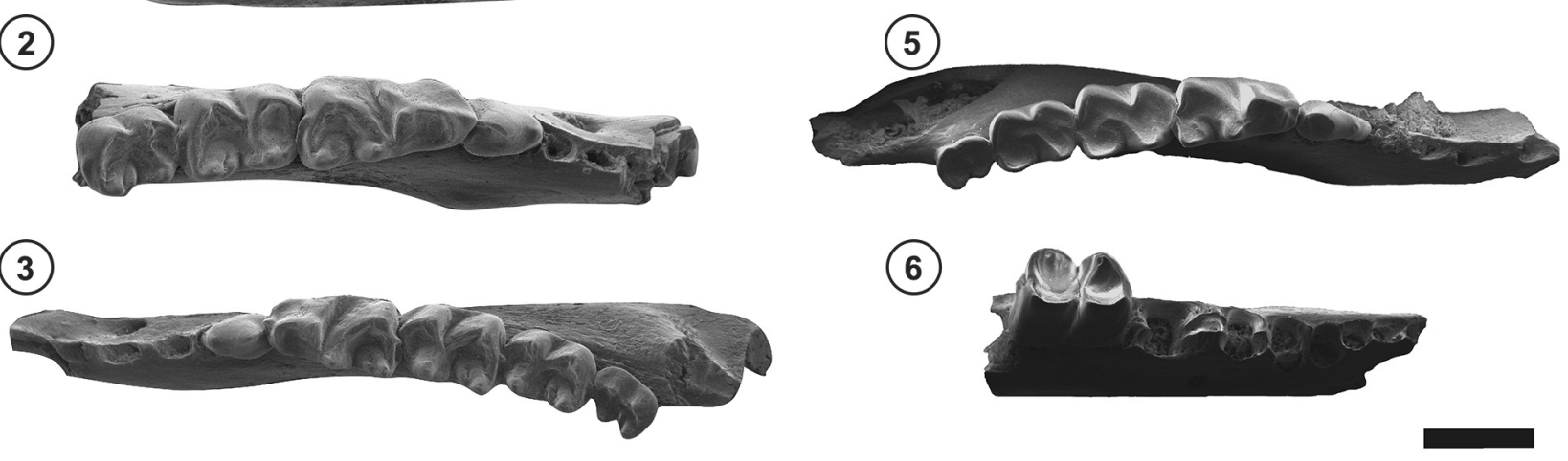

(6)
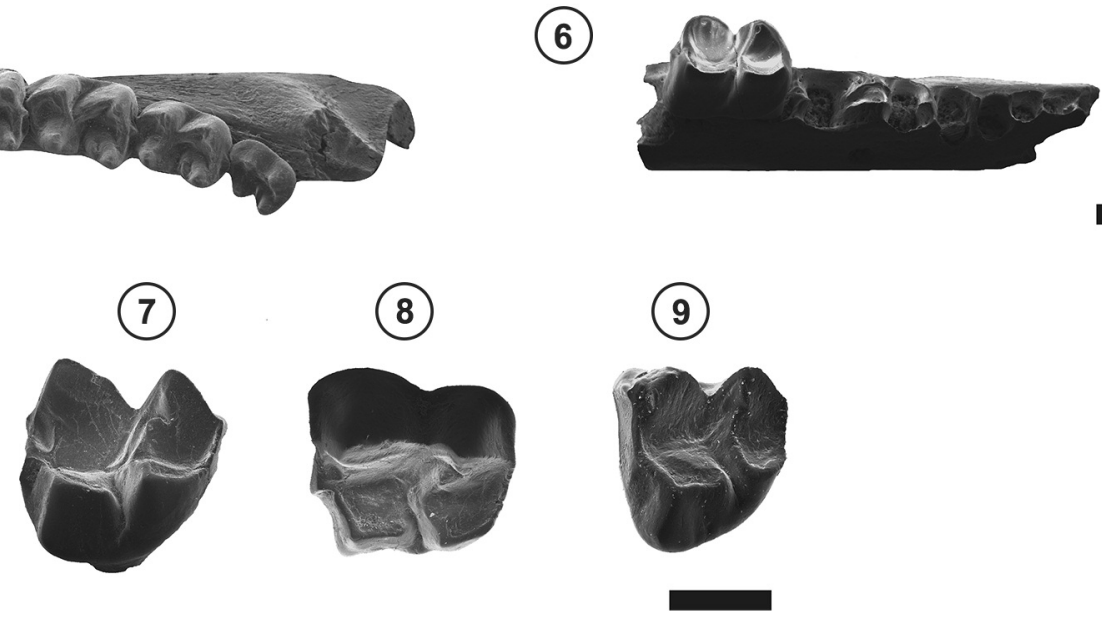

Figure 11. 1-3, Palaeothentes intermedius, MACN-A 2 (type specimen); 1, labial view; 2, occlusal view; 3-9, P. minutus, MACN-A 15 (type specimen); 3, occlusal view; 4, lingual view; MPM-PV 19393; 5, occlusal view; MPM-PV 19379; 6, occluso-labial view; MPM-PV 19397; 7, lingual view; 8, occlusal view; MPM-PV 19400; 9, occluso-lingual view. 1-6, Scale bar 2=mm; 7-9, Scale bar= 1 mm.

terior margin of the tooth. Finally, its size is intermediate to the smaller $P$. minutus and the larger $P$. lemoinei.

\section{Palaeothentes minutus Ameghino, 1887}

Figure 11.3-9; Tables 1-3

Holotype. MACN-A 15, right dentary fragment with p3-m4 (Fig. 11.3-4).

Stratigraphic and Geographic distribution. Province of Santa Cruz (Argentina). Pinturas Formation at Río Pinturas: Estancia Los Toldos, Cerro de los Monos, Estancia Ana María, Loma de la Lluvia, Portezuelo Sumich Sur, Estancia El Carmen, and Río Chalía. Santa Cruz Formation: RSC, Killik-Aike, La Cueva, Río Gallegos, Río Chalía, and Cerro Observatorio.

Referred material. MPM-PV 19379, right dentary fragment with m3 (Fig. 11.6); MPM-PV 19391; left dentary fragment with p3, m2-4; MPM-PV 19392, right dentary fragment with m1-3; MPM-PV 19393, left dentary fragment with p3m4 (Fig. 11.5); MPM-PV 19395, an isolated right m2; MPMPV 19396, right dentary fragment with m2-3; MPM-PV 19397, isolated left M2 (Fig. 11.7-8); MPM-PV 19398, right dentary fragment with p3-m2; MPM-PV 19399, left dentary fragment with m2-3; MPM-PV 19400, an isolated left M2 (Fig. 11.9); MPM-PV 19401, left dentary fragment with m2-3; MPM-PV 19402, left dentary fragment with m2-3; MPM-PV 19403, right dentary fragment with m1-2; MPMPV 19404, right dentary fragment with m1; MPM-PV 19405, right dentary fragment with m2; MPM-PV 19406, left dentary fragment with p3-m2; MPM-PV 19407, right dentary fragment with m2-3; MPM-PV 19408, left dentary 
fragment with p3, m2-4; MPM-PV 19409, left dentary fragment with m2-3.

Geographic distribution. BB: MPM-PV 19379, MPM-PV 19391, MPM-PV 19392, and MPM-PV 19393 come from EAG, MPM-PV 19395 comes from ESL; SBB: MPM-PV 19396, MPM-PV 19397, and MPM-PV 19408 were exhumed from EET, MPM-PV 19398, MPM-PV 19399, MPMPV 19400, MPM-PV 19401, MPM-PV 19402, MPM-PV 19403, MPM-PV 19404, MPM-PV 19405, MPM-PV 19406, MPM-PV 19407, and MPM-PV 19409 come from ECA.

Comments on the holotype. Originally, Ameghino (1887) described Palaeothentes minutus as the smallest species of the genus and gave measurements of the mandible. He mentioned the p3-m1 [p3-4] and m2-4 [m1-m3]. Ameghino (1889: pl.1, fig. 16) did not give many more details and illustrated a right dentary fragment with $\mathrm{m} 1-3$ and the alveoli of the m4. Later, he designated other specimens to the species (e.g., Ameghino, 1894). The specimen MACN-A 15 (labeled as type in Ameghino's catalogue) corresponds to a right dentary fragment. It includes all the dental loci mentioned by Ameghino (1887, 1889), the mental foramen below the $\mathrm{m} 1$ [p4], and the measurements are similar to those stated by Ameghino (1887). There is no way of knowing if Ameghino based P. minutus in a single specimen or a syntype. We consider, as have other authors (e.g., Marshall, 1980; Abello, 2007), that MACN-A 15 is with almost certainty the type of the species.

Comments on the referred material. Palaeothentes minutus is one of the smallest species of the genus, only P. migueliand $P$. pascuali are smaller. Among the larger specimens is the holotype, and MPM-PV 19404, MPM-PV 19406, and MPMPV 19409. The smaller specimens include MPM-PV 19396, MPM-PV 19403, and MPM-PV 19407. The latter specimen is very worn, and the size is almost as small as $P$. migueli and $P$. pascuali but the $\mathrm{m} 1$ has a longer and straighter paracristid, while the cristid oblicua is more parallel to the dentary axis, as it occurs in P. minutus but not in $P$. migueli and $P$. pascuali.

Order Microbiotheria Ameghino, 1889 Family MıcrobIOTHERIIDAE Ameghino, 1887

Genus Microbiotherium Ameghino, 1887
Type species. Microbiotherium patagonicum Ameghino, 1887. Santa Cruz Formation, Barrancas del RSC, Province of Santa Cruz, Argentina.

Microbiotherium patagonicum Ameghino, 1887

Neotype (designated in this paper). MLP 11-30, right dentary fragment with m1-3 (originally, also m4 was present) and alveoli of $\mathrm{p} 1-3$.

\section{Stratigraphic and Geographic distribution. Santa Cruz Formation} at Province of Santa Cruz in the following localities: RSC, La Cueva, Río Chalía, Cerro Observatorio.

Neotype designation. Ameghino (1887) made a brief description of a mandible with, at least the m2-3 [m1-2]. Later, Ameghino (1889) commented that the species was based on a left dentary fragment with the three true molars (i.e., today's m2-4) and, anteriorly, only the alveoli of the other loci. Years later, Ringuelet (1953) argued that the right dentary fragment with m1-4 MLP 11-30 was the type specimen of $M$. patagonicum and commented that Ameghino (1889) could made a mistake assigning the type to a left dentary, because he was no longer working in the Museo de La Plata, and he could not see the specimen again (Ringuelet, 1953: pl. 1, fig. 4). Even if that was the case, he omitted to say that the dentary (MLP 11-30) had four complete teeth, not three as he stated. These discrepancies suggest that MLP 11-30 is not the type of the species. The archives from the MLP collection for the specimen MLP 1130 state that the specimen was collected by C. Ameghino from Santa Cruz, and the label of the specimen also has written that it comes from the "Bcas. del río Santa Cruz", but this labels are not the original one and the paper archive has no data but "Santa Cruz" and "Santacrucense". Since the labels are not the original ones and, by 1887 the term "Santacrucense" was not in use, it is possible that the information is inaccurate (see Fernicola, 2011).

Given the information stated above, and trying to clarify the taxonomic status of the species and understanding that the type is lost, we designate MLP 11-30 as the neotype of Microbiotherium patagonicum, following Art. 75 (75, 1 to 75.7) of the International Code of Zoological Nomenclature. The neotype comes from the same unit as the type, and has been considered the type by several authors since Riguelet (1953) because the features of the dentary match with 
those stated in the original description (Ameghino, 1887).

Microbiotherium tehuelchum Ameghino, 1887

Figure 12.1-6; Tables 1, 2

Neotype. MLP 11-36, right dentary fragment with p1-m4 (Marshall, 1982).

Stratigraphic and geographic distribution. In Chile, Río Frías Formation (Aysén). In the Province of Santa Cruz (Argentina) from Pinturas Formation (Río Pinturas): Cerro de Los Monos, and Portezuelo Sumich Sur, and SCF: RSC, Corriguen-Kaik, La Cueva, Yegua quemada, Cerro Observatorio, and Killik Aike Norte.

Referred material. MPM-PV 19372, right dentary fragment with broken $\mathrm{p} 3$ and complete $\mathrm{m} 1$ (Fig. 12.1, 4-5); MPM-PV 19373, left dentary fragment with $\mathrm{m} 1$ (Fig. 12.2-3, 6).

Geographic distribution. SBB: Both specimens come from ECA. Comments on the holotype. When Ameghino (1887) recognized the species Microbiotherium tehuelchum, he described some premolar and molar loci (p3-m4). Ameghino (1889) commented that, even though he based the species on several mandibular fragments, the most complete of them corresponds to a left mandibular ramus with the p3-m4. However, he figured a dentary fragment with two molars
(Ameghino, 1889: pl. 1, fig. 17). According to Marshall (1982) this fragment was "an unidentified member of the caenolestid subfamily Palaeothentinae". Nevertheless, the resemblance with the caenolestids could be an artifact induced by the extreme wear of the molars, thus giving the appearance of a bilobate occlusal surface (as occurs with MACN-A 2026, dentary fragment with two molars and the trigonid of a third). The interpretation of the figure in Ameghino's Atlas is difficult because of the style of the drawing, and no specimen totally coincides with it.

Ringuelet (1953) described M. tehuelchum, and considered the specimen MLP 11-36 as a possible cotype of the species, being similar and with the same measurements than the ones presented by Ameghino (1887, 1889). Pascual and Herrera (1975) considered it the type, and finally Marshall (1982) designated it as the Neotype, based on having a general description coincident with original from Ameghino (1887) and being located in the MLP collection, as was the original sintype, even though he considered it as having no locality data. The problem with this assignation, as recognized by Marshall (1982), is that MLP 11-36 has more preserved premolars than the best specimen described by Ameghino $(1887,1889)$, thus probably not being part of the original sintype.
(1)

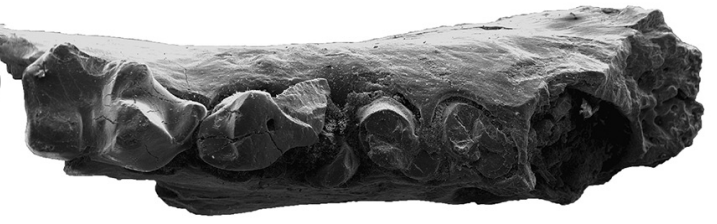

(4)

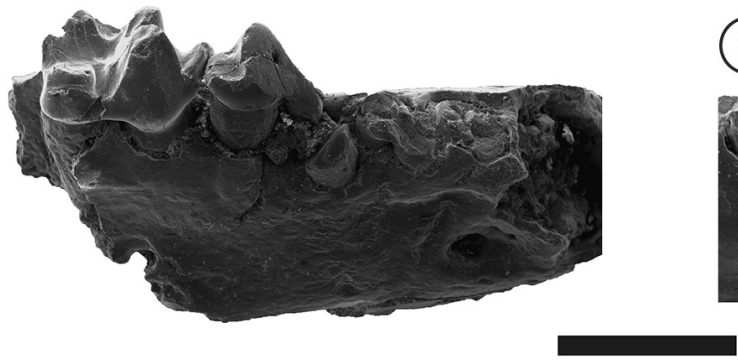

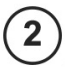

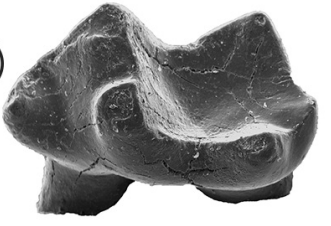

3

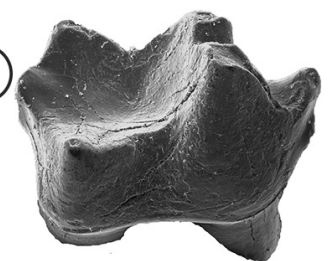

(5)

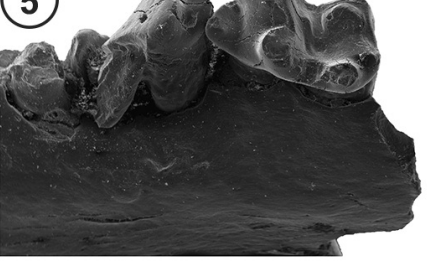

(6)

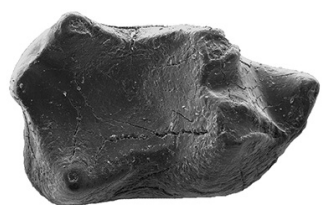

Figure 12. 1-6, Microbiotherium tehuelchum, MPM-PV 19372; 1, occlusal view; 4, occluso-labial view; 5, lingual view; MPM-PV 19373; 2, lingual view; 3, labial view; 6, occlusal views; $1,4-5$, scale bar= $2 \mathrm{~mm} ; 2-3,6$, scale bar= $1 \mathrm{~mm}$. 
The record of the catalog of MLP 11-36 indicates "Barrancas del Río Santa Cruz", but this could have been written after later interpretations because Marshall (1982) commented that the MLP 11-36 was "without locality data".

Finally, there is a specimen, MACN-A 1, labeled as type in Ameghino's catalogue, corresponding to a right dentary fragment with $\mathrm{p} 1-\mathrm{m} 1$. This specimen was considered as part of Microbiotherium patagonicum by Marshall (1982), even accepting that could be part of the original sintype of M. tehuelchum. This specimen is not the most complete mandible mentioned by Ameghino (1889) and has not the same proportions and we accept Marshall's assignment to M. patagonicum.

In this state of knowledge it can be argued that $M$. tehuelchum, following Marshall's neotype that this is the first record of $M$. tehuelchum in the RSC.

Comments on the referred material. The specimen MPM-PV 19372 is similar to $M$. tehuelchum in size and on its molar general features: para- and metaconid are set close together, and the talonid and trigonid are similar in width (contrary to a narrower trigonid in Oligobiotherium Ameghino, 1902) but not so much as in M. patagonicum.

Specimen MPM-PV 19373 is almost identical to the neotype, only has a slightly more mesially projected paraconid.

\section{DISCUSSION}

\section{Ameghino's metatherian types from the RSC}

When Ameghino (1887) first described the mammalian fauna from the RSC he based the metatherian species either on a single or several specimens. When he left the Museo de La Plata in 1888 he left some specimens there, but took several others from the RSC with him that were subsequently deposited in the Museo Nacional de Historia Natural, now MACN-A (Marshall, 1980; Fernicola, 2011).

Of the RSC species described by Ameghino (1887, 1889) still considered to be valid there are eleven identifiable type specimens still known. Some of them are in the MLP collections: MLP 11-103 (holotype of Cladosictis patagonica), MLP 11-64 (holotype of Acyon ticuspidatus), MLP 11-108 (holotype of Borhyaena tuberata), MLP 11-70 (holotype of Acrocyon sectorius), and MLP 11-93 (holotype of Palaeothentes aratae). Other type specimens are retained in the MACN-A collections: MACN-A 684 (holotype of Perathereutes pungens), MACN-A 12 (holotype of Abderites meridionalis), MACN-A 1379 (holotype of Acdestis oweni), MACN-A 3 (holotype of Palaeothentes lemoinei), MACN-A 2 (lectotype of Palaeothentes intermedius), and MACN-A 15 (holotype of Palaeothentes minutus). Since the MACN-A specimens correspond to original type of the species from the RSC, it appears that at least these six type specimens were appropriated by Ameghino from the MLP collection.

From his position in the Museo Nacional de Historia Natural (now MACN), Ameghino started his catalogue and numbered the specimens from his personal collection and, in some cases, designated new types. Moreover, in later papers he figured or described sometimes the species based on other specimens. Because of this, some authors confused such specimens as types (such is the case with Sipalocyon gracilis, figured in Ameghino, 1894, and marked as type in his catalogue). In other cases, some reviewers wrongly interpreted which specimen was the original type, as with Microbiotherium patagonicum mentioned by Ringuelet (1953). Finally, because several types are not to be found in either the MLP or in MACN collections, a few specimens were selected as neotypes (such as in Stilotherium dissimile Reig, 1955). All this changes, confusions, and considerations highlight the need for caution when citing a list of metatherians from the RSC in a biogeographical or a biostratigraphical context; sometimes, even though the species was originally described from RSC, a neotype was erected from another locality or without specific locality data.

\section{The metatherian record from the RSC}

In today's view and taking into account the valid species, the taxonomic list of the Metatheria from the RSC is the following (Cabrera, 1927; Marshall, 1978, 1980, 1982; Abello, 2007; Abello et al., 2012; Prevosti et al., 2012; Prevosti and Forasiepi, 2018):

Sparassodonta: Borhyaena tuberata, Acrocyon sectorius, Lycopsis torresi, Cladosictis patagonica, Acyon tricuspidatus, Sipalocyon gracilis, and Perathereutes pungens.

Paucituberculata: Palaeothentes aratae, P. lemoinei, P. intermedius, P. minutus, Acdestis oweni, Abderites meridionalis, and Stilotherium dissimile.

Microbiotheria: Microbiotherium patagonicum, and M. tehuelchum. 
Three localities are recognized for the RSC outcrops of the SCF (Fernicola et al., 2014). From east to west, BB, SBB, and $\mathrm{YH}$. In this study, we recognized 10 species of metatherians from BB and SBB. Nine of them were already described by Ameghino (1887) and one species (Perathereutes pungens) was previously known only from Cerro Observatorio, La Cueva and Puesto Estancia la Costa (Prevosti et al., 2012).

No Metatheria is here reported from YH. From BB come the following species: Borhyaena tuberata, Sipalocyon gracilis, Acdestis oweni, Palaeothentes minutus, P. lemoinei, and Abderites meridionalis. From SBB: B. tuberata, S. gracilis, P. pungens, $C$. patagonica, A. oweni, P. minutus, P. lemoinei, P. intermedius, A. meridionalis, and $M$. tehuelchum. As can be observed, the species richness varies among the localities, since ten species have been found in SBB, but only six come from BB.

Following Cuitiño et al. (2016), SBB have the youngest vertebrate fossil levels from the RSC, but nevertheless, SBB and $\mathrm{BB}$ are younger than several localities from the Atlantic coast (i.e., Estancia La Costa, Cañadón Silva, Puesto Estancia La Costa, Monte Tigre, Cabo Buen Tiempo, and Killik Aike Norte).

It is not known whether the RSC species described by Ameghino (1887) come from BB, SBB, or even $\mathrm{YH}$, and whether the species from Cerro Observatorio and Monte León were recorded from the upper or lower parts of those localities. However, the coastal localities mentioned above could better represent a similar time of deposition, older than the ones from SBB and BB (see Cuitiño et al., 2016). Taking into account the species that are restricted in age from the Atlantic coast, and the RSC (BB + SBB), the following are shared: Borhyaena tuberata, Cladosictis patagonica, Sipalocyon gracilis, Perathereutes pungens, Palaeothentes lemoinei, P. minutus, and Microbiotherium tehuelchum. Lycopsis torresi and Palaeothentes aratae are found in both regions, but it is unknown the specific RSC localities from which they were exhumed. Finally, six species with no exact locality are found in the RSC but not in the coastal localities mentioned above (Acyon tricuspidatus, Palaeothentes intermedius, Acdestis oweni, and Microbiotherium patagonicum), while four species of the coastal older localities are not found in the RSC (Arctodictis munizi, Phonocdromus gracilis, Microbiotherium gallegosense, and Microbiotherium acicula). These differences could argue in favor of some differences caused by age or area bias. However, since numerous species recovered from some sites have no stratigraphic data (e.g., old RSC collections, Cerro Observatorio, Monte León; Cuitiño et al., 2016), we lack enough evidence to arrive to a solid conclusion.

\section{CONCLUSIONS}

The study of the new records of metatherians from the RSC at BB and SBB led to a thorough searching of Ameghino's (1887) original types and descriptions made by him. We have now identified the lost type of Paleothentes aratae (MACN-A 1340), and we designate two neotypes, the MACN-A 647 for Sipalocyon gracilis and the MACN-A 11-30 for Microbiotherium tehuelchum. The three specimens were erroneously considered as the original types by several authors (e.g., Ringuelet, 1953; Marshall, 1980, 1981, 1982; Abello, 2007; Forasiepi, 2009), the specimen MACN-A 2 is recognized here as the lectotype of Palaeothentes intermedius (assigning its implicit recognition to Marshall, 1980).

The study of the new specimens collected in BB and SBB, plus the original ones recognized by Ameghino (1887) give a total of 16 metatherian species from the SCF levels of the RSC: seven Sparassodonta, seven Paucituberculata, and two Microbiotheria. Ten species from the new collections were recognized. Only one species (Perathereutes pungens) was not previously recorded in the RSC. In SBB all ten species were recognized, four more than in BB. Several species from the RSC are found also in coastal older localities. However, since much information is lacking on the exact place in the geological section for where the metatherian species occur at several SCF localities (e.g., specimens from RSC and Cerro Observatorio), no precise conclusions can be made as to the age/distribution of the types.

\section{ACKNOWLEDGMENTS}

We are grateful to the editors of this volume, J.C. Fernicola, S.F. Vizcaíno, M.S. Bargo, and R.F. Kay for inviting us to participate. To N.A. Muñoz, S. Hernández del Pino, M. Fernández, J. Cuitiño, L. Gonzalez, J. Perry for the fieldwork. To F. Tricárico for the SEM photographs. To C. Sciocia, who helped with discussions about the ICZN. To the reviewers, who helped improved this paper. This is a contribution to projects PICT 201-0508, PIP-CONICET 00781, PUE 22920160100098, UNLP 11/N867, PICT 2013-0389, and 20171081, National Science Foundation grants 0851272 and 1348259, and National Geographic Society 9167-12. 


\section{REFERENCES}

Abello, M.A. 2007. [Sistemática y bioestratigrafía de los Paucituberculata (Mammalia, Marsupialia) del Cenozoico de América del Sur. Ph.D. Thesis, Facultad de Ciencias Naturales y Museo, Universidad Nacional de La Plata, 456 p. Unpublished.].

Abello, M.A. 2013. Analysis of dental homologies and phylogeny of Paucituberculata (Mammalia: Marsupialia). Biological Journal of the Linnean Society 109: 441-465.

Abello, M.A., Ortiz-Jaureguizar, E., and Candela, A.M. 2012. Paleoecology of the Paucituberculata and Microbiotheria (Mammalia, Marsupialia) from the late early Miocene of Patagonia. In: S.F. Vizcaino, R.F. Kay, and M.S. Bargo (Eds.), Paleobiology in Patagonia. Reconstructing a high-latitude paleocommunity in the early miocene climatic optimum. Cambridge University Press, Cambridge, p. 156-172.

Abello, M.A., and Rubilar-Rogers, D. 2012. Revisión del género Abderites Ameghino, 1887 (Marsupialia, Paucituberculata). Ameghiniana 49: 164-184.

Ameghino, F. 1887. Enumeración sistemática de las especies de mamíferos fósiles coleccionados por Carlos Ameghino en los terrenos eocenos de la Patagonia y depositados en el Museo de La Plata. Boletín del Museo de La Plata 1: 1-26.

Ameghino, F. 1889. Contribución al conocimiento de los mamíferos fósiles de la República Argentina. Actas de la Academia Nacional de Ciencias de Córdoba 6: 33-1027.

Ameghino, F. 1891. Nuevos restos de mamíferos fósiles descubiertos por Carlos Ameghino en el Eoceno inferior de la Patagonia austral. Especies nuevas, adiciones y correcciones. Revista Argentina de Historia Natural 1: 289-328.

Ameghino, F. 1894. Enumération synoptique des espéces de mammifères fossiles des formations éocènes de Patagonie. Boletín de la Academia Nacional de Ciencias de Córdoba 13: 259-452.

Ameghino, F. 1902. Première contribution à la connaissance de la faune mammalogique des couches à Colpodon. Boletín de la Academia Nacional de Ciencias de Córdoba 17: 71-138.

Bown, T.M., and Fleagle, J.G. 1993. Systematics, bioestratigraphy and dental evolution of the Palaeothentidae, Late Oligocene to Early-Middle Miocene (Deseadan-Santacrucian) Caenolestoid marsupials of South America. Paleontological Society, Memoir 29: $1-76$.

Cabrera, A. 1927. Datos para el conocimiento de los Dasiuroideos fósiles argentinos. Revista del Museo La Plata 30: 271-315.

Cuitiño, J.I., Fernicola, J.C., Kohn, M.J., Trayler, R., Naipauer, M., Bargo, M.S., Kay, R.F., and Vizcaíno, S.F. 2016. U-Pb geochronology of the Santa Cruz Formation (early Miocene) at the Río Bote and Río Santa Cruz (southernmost Patagonia, Argentina): Implications for the correlation of fossil vertebrate localities. Journal of South American Earth Sciences 70: 198-210.

Engelman, R.K., Anaya, F., and Croft, D.A. 2015. New specimens of Acyon myctoderos (Metatheria, Sparassodonta) from Quebrada Honda, Bolivia. Ameghiniana 52: 204-225.

Ercoli, M.D., Prevosti, F.J., and Forasiepi, A.M. 2014. The structure of the mammalian predator guild in the Santa Cruz Formation (late early Miocene). Journal of Mammalian Evolution 21: 369-381.

Fernicola, J.C. 2011. Implicancias del conflicto Ameghino-Moreno sobre la colección de mamíferos fósiles realizada por Carlos Ameghino en su primera exploración al río Santa Cruz, Argentina. Revista del Museo Argentino de Ciencias Naturales, Nueva Serie 13: 41-57.

Fernicola, J.C., Bargo, M.S., Vizcaíno, S.F., and Kay, R.F. 2019. Historical background for a revision of the paleontology of the
Santa Cruz Formation (Early-Middle Miocene) along the Río Santa Cruz, Patagonia, Argentina. In: J.C. Fernicola, M.S. Bargo, S.F. Vizcaíno and R.F. Kay (Eds.), Early-Middle Miocene Paleontology in the Río Santa Cruz, Southern Patagonia, Argentina. 130 years since Ameghino, 1887. Publicación Electrónica de la Asociación Paleontológica Argentina 19: 1-13.

Fernicola, J.C., Cuitiño, J.I., Vizcaíno, S.F., Bargo, M.S., and Kay, R.F. 2014. Fossil localities of the Santa Cruz formation (early Miocene, Patagonia, Argentina) prospected by Carlos Ameghino in 1887 revisited and the location of the Notohippidian. Journal of South American Earth Science 52: 94-107.

Fitz Roy, R. 1837. Extracts from the diary of an attempt to ascend the River Santa Cruz, in Patagonia, with the boats of H.M.S. Beagle. Journal of the Royal Geographical Society of London 7: 1-126.

Forasiepi, A.M. 2009. Osteology of Arctodictis sinclairi (Mammalia, Metatheria, Sparassodonta) and phylogeny of Cenozoic metatherian carnivores from South America. Monografía del Museo Argentino de Ciencias Naturales 6: 1-174.

Forasiepi, A.M., Sánchez-Villagra, M.R., Goin, F.J., Takai, M., Kay, R.F., and Shigehara, N. 2006. A new Hathliacynidae (Metatheria, Sparassodonta) from the middle Miocene of Quebrada Honda, Bolivia. Journal of Vertebrate Paleontology 26: 670-684.

Marshall, L.G. 1978. Evolution of the Borhyaenidae, extinct South American predaceous marsupials. University of California Publications in Geological Sciences 117: 1-89.

Marshall, L.G. 1980. Systematics of the South American marsupial family Caenolestidae. Fieldiana: Geology, New Series 5: 1-145.

Marshall, L.G. 1981. Review of the Hathlyacyninae, an extinct subfamily of South American "dog-like" marsupials. Fieldiana: Geology, New Series 7: 1-120.

Marshall, L.G. 1982. Systematics of the South American marsupial family Microbiotheriidae. Fieldiana: Geology, New Series 10: 1-75.

Mercerat, A. 1891. Caracteres diagnósticos de algunas especies de Creodonta conservadas en el Museo de La Plata. Revista del Museo de La Plata 2: 51-56.

Moreno, F.P. 1879. Viaje a la Patagonia Austral, emprendido bajo los auspicios del Gobierno Nacional, 1876-1877. La Nación Press, Buenos Aires, $246 \mathrm{p}$.

Moreno, F.P. 1882. Patagonia. Resto de un antiguo continente sumergido. Anales de la Sociedad Científica Argentina 14: 97-131.

Pascual, R., and Herrera, H.E. 1975. Stilotherium Ameghino, 1887, el más primitivo Caenolestidae conocido. Consideraciones sobre la transicion Didelphidae-Caenolestidae (Marsupialia). $1^{\circ}$ Congreso Argentino de Paleontología y Bioestratigrafía (Tucumán), Actas 2: 417-430.

Prevosti, F.J., and Forasiepi, A.M. 2018. Evolution of South American mammalian predators during the Cenozoic: Paleobiogeographic and Paleoenvironmental Contingencies. Springer Geology, Springer International Publishing, $196 \mathrm{p}$.

Prevosti, F.J., Forasiepi, A.M., Ercoli, M.D., and Turazzini, G.F. 2012. Paleoecology of the mammalian carnivores (Metatheria, Sparassodonta) of the Santa Cruz Formation (late early Miocene). In: S.F. Vizcaíno, R.F. Kay, and M.S. Bargo (Eds.), Early Miocene Paleobiology in Patagonia: High-latitude Paleocommunities of the Santa

Cruz Formation. Cambridge University Press, Cambridge, p. 173-193.

Reig, O.A. 1955. Un nuevo género y especie de cenolestinos del Plioceno de la Provincia de Buenos Aires. Revista de la Asociación Geológica Argentina 10: 60-71.

Ringuelet, A.B. 1953. Revisión de los Didélfidos fósiles argentinos. Revista del Museo de La Plata, Nueva Serie 2: 265-308. 
Sinclair, W.J. 1906. Marsupials of the Santa Cruz beds. Princeton University Expeditions to Patagonia 4: 330-460.

Trouessart, E.L. 1898. Catalogus mammalium tam viventium quam fossilium. Nova editio R. Friedländer \& Sohn, Berlin 2: 665-1264.

Vizcaíno, S.F., Kay, R.F., and Bargo, M.S. 2012. Early Miocene Paleobiology in Patagonia: High-latitude Paleocommunities of the Santa Cruz Formation. Cambridge University Press, Cambridge, 378 p.

Doi: 10.5710/PEAPA.04.10.2019.287

Recibido: 22 de marzo 2019

Aceptado: 4 de octubre 2019 